\title{
Influence of selected activating methods on hydration processes of mixtures containing high and very high amount of fly ash
}

\section{A review}

\author{
Iwona Wilińska' ${ }^{1}$ Barbara Pacewska ${ }^{1}$
}

Received: 10 September 2017 / Accepted: 7 December 2017 / Published online: 3 January 2018

(C) The Author(s) 2018. This article is an open access publication

\begin{abstract}
Binders containing fly ash as cement substitute have been used for many years. Typical amount of fly ash in cement composite does not exceed 35\% of mass of binder. Replacement of substantial amount of cement mass by fly ash results in retardation of hydration of binder and deterioration of some concrete properties, e.g. delay in setting time and reduction in early compressive strength. These inconveniences may be reduced using proper method of activation. In this paper, possibilities to activate binding mixtures containing high and very high amount of fly ash and low amount of Portland cement were discussed basing on the literature reports as well as on our own research results. Several activating methods were described, such as mechanical activation, exchanging of part of components of binder (cement, fly ash or both of them) by more reactive fine-grained material, chemical activation by the use of alkaline activators as well as combined methods. Possibilities of using these methods were discussed in relation to amount of fly ash introduced as replacement of cement and kind of fly ash used. Usefulness of calorimetry and thermal analysis methods was also presented.
\end{abstract}

Keywords Fly ash $\cdot$ Activation $\cdot$ Hydration $\cdot$ Cement $\cdot$ TG/DTG $\cdot$ Calorimetry

\section{Introduction}

Portland cement is a common binder used in construction materials. However, its production (especially clinkerisation process) generates several ecological and economic problems, such as consumption of great amount of energy and natural resources as well as emission of $\mathrm{CO}_{2}$. Different activities are undertaken to minimise these inconveniences, especially concerning reduction in emission of $\mathrm{CO}_{2}$ [1]. One of them is utilisation of the supplementary cementitious materials (e.g. fly ash) in manufacture of cement and concrete. Cements containing different clinker substitutes, e.g. fly ash or slag, are currently often used. For example, cement CEM II may contain from 6 to 20 or from 21 to

Barbara Pacewska

barbara.pacewska@pw.edu.pl

1 Faculty of Civil Engineering, Mechanics and Petrochemistry, Institute of Chemistry, Warsaw University of Technology, 17 Łukasiewicza St., 09-400 Plock, Poland
$35 \%$ of fly ash according to standard PN-EN 197-1:2012 [2]. Fly ash of adequate properties (acc. PN-EN 450-1:2012 [3]) may be also used as type II additive for concrete. In this way, using supplementary cementitious materials some reduction in problems related to cement production is possible to obtain. Moreover, using for this purpose byproducts arising in industry (e.g. fly ash from hard coal combustion produced in energy industry) gives additional ecological advantages. Such actions are part of a sustainable development policy.

Theoretically, the higher the level of substitution of Portland cement by other aluminosilicate material, the greater the ecological benefits should be expected. However, replacement of substantial amount of cement in binder mass by fly ash gives significant deterioration of concrete properties and limitation of possibilities of practical use of such material. Thus, fundamental question appears: what is the amount of fly ash that can be used in this way? The simplest answer is: it depends on role of fly ash in binding mixture. 


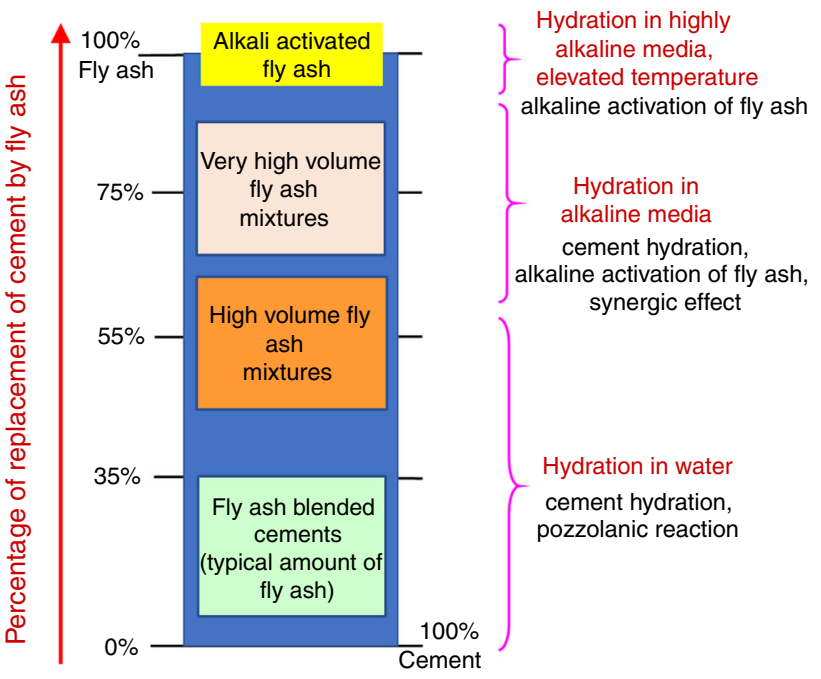

Fig. 1 Scheme presenting general possibilities of cement replacement by fly ash in binding mixtures and needed conditions of hardening

Several groups of binding mixtures depending on the amount of fly ash can be found in the literature as it is presented in Fig. 1. Portland cement as typical, classical binder composed without fly ash is at the one of extreme point in the diagram. From the opposite side, there is alkali activated binder composed of $100 \%$ of fly ash [4-10]. Between them one can specify:

- fly ash cements containing not higher than $35 \%$ of fly ash (it is typical amount of fly ash),

- high volume fly ash binders containing about 50\% and higher of fly ash as cement replacement [11-15],

- very high volume fly ash mixtures containing above $70 \%$ of fly ash [16-20].

Cement hydration and pozzolanic reaction of fly ash (reaction of active silica and alumina with $\left.\mathrm{Ca}(\mathrm{OH})_{2}\right)$ are well known [21, 22]. Such processes take place in mixture of cement and fly ash in the presence of water. Development of early compressive strength of composites containing pozzolanic replacements of cement depends on amount of supplementary cementitious material used, its type [23] and conditions of hardening. Replacement of substantial amount of cement mass by fly ash gives important inconveniences, such as retardation of the binder hydration and, as a result, deterioration of some concrete properties, e.g. delay in setting time and reduction in early strength. In case of high volume fly ash concrete, these inconveniences may be reduced by significant reduction in water to cement ratio with simultaneous use of superplasticisers (e.g. in works $[12,24,25])$ or by optimal amounts of components and proper curing $[17,26]$. Better results of early strength in the case of the presence of superplasticisers may be explained by better dispersion of grains of binders making their surface more available for water [27]. However, despite improved dispersion, some water reducing admixtures may cause significant delay of initial reactions of hydration [19]. For mixtures containing very high amount of fly ash, extremally low amount of cement causes that hydration in water may be insufficient. Such materials need special activators for hardening.

There are few methods of activation of fly ash-cement binders resulting in improvement in their properties especially in early periods of hardening: mechanical activation, chemical activation, thermal treatment and combined methods joining different methods of activation (Fig. 2). Each of these methods influences physicochemical processes occurring in the binders in the presence of water. Several mechanisms of improvement in properties of such binding mixtures may be considered: acceleration of cement hydration and/or pozzolanic reaction, improvement in reactivity of supplementary cementitious material by enhancement of dissolution of its aluminosilicate grains, arising additional products in the presence of chemical activators.

Aluminosilicate supplementary cementitious materials containing low amount of calcium components (e.g. conventional pulverised fly ash from hard coal combustion) do
Fig. 2 Typical ways of activation of fly ash-cement mixtures

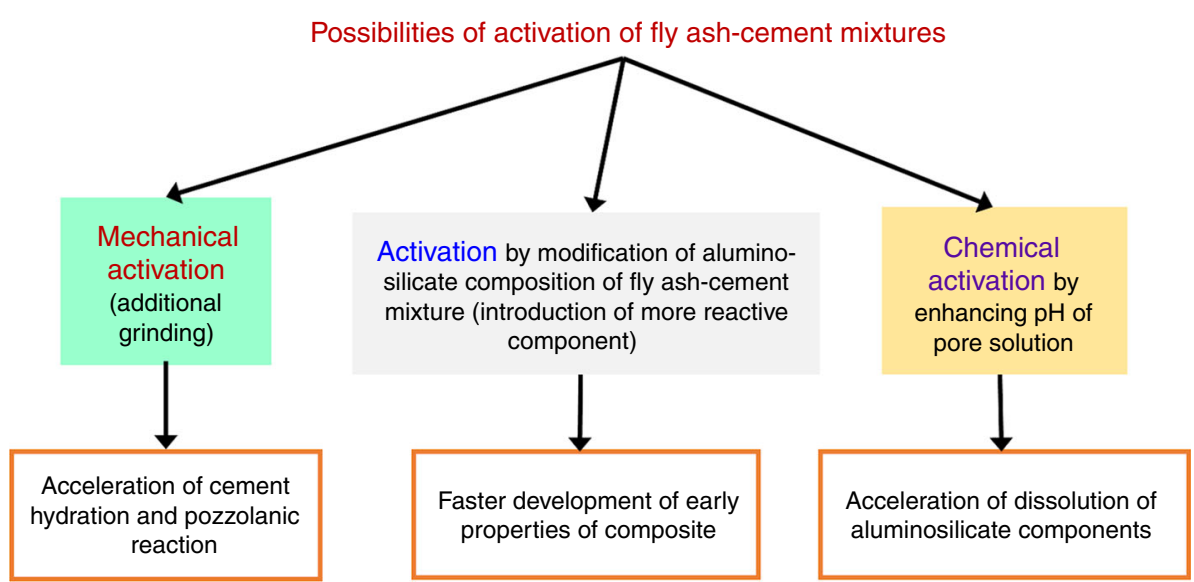


not exhibit self-cementing properties and therefore do not harden in water. They undergo reaction with $\mathrm{Ca}(\mathrm{OH})_{2}$ (pozzolanic reaction), but they can also harden under other alkaline solutions of high $\mathrm{pH}$ (e.g. $\mathrm{NaOH}$ solution). That is why alkaline components are necessary most of all in case of non-clinker binders (geopolymers) composed from aluminosilicate material, such as fly ash, without cement. Elevated temperature of hardening often is needed in case of such mixtures. Aluminate and silicate species dissolve from fly ash grains in highly alkaline conditions. Then, they undergo complex processes of polymerisation and polycondensation. Consequently, solid product precipitates. Depending on the type of aluminosilicate source material as well as conditions of reaction (such as concentration of alkali and temperature), this product may be zeolitic or amorphous [4-6, 8, 9]. There are also research reports concerning utilisation of fly ash from fluidised combustion of coal as activator for slag component in nonclinker mixture [28, 29].

High volume fly ash composites can be considered as sustainable ecological products_- "green" concretes. There are possibilities of applications for such materials despite the deterioration of some properties compared to cement concrete. The examples may be: controlled low-strength composite [30] or massive foundation slab [31, 32]. Concrete containing high amount of fly ash as replacement of cement can develop its properties with time. Proper design and realisation of high volume fly ash concrete results in high-performance material. Such composites containing about $50 \%$ of fly ash of good quality in binder, properly selected type and amount of cement, low amount of water and superplasticising admixture and subjected to properly long moist-curing can achieve high ultimate strength and durability $[33,34]$. Binder containing very high amount of cement replacement (about $65 \%$ of mixture of fly ash and slag) and alkaline activator was produced and investigated as pre-industrially manufactured hybrid cement [35].

The necessity to discover new, ecologically friendly binders which could be an alternative to Portland cement necessitates that research works recognising mechanism of hardening of activated mixtures are still needed. Such studies are important from scientific as well as practical points of view, as they provide a basis for predicting the long-term properties of hardened composite. It is possible to obtain material of good properties during alkaline activation of aluminosilicates. However, alkali activated nonclinker binders (geopolymers) need high alkaline solutions and often elevated temperature for hardening. It causes some ecological problems and raise in price of the final product. Some problems with safety of workers relating to using high alkaline solutions also appear [16, 36]. Thus, recently, special emphasis is put to develop activated binders which can harden in more mild conditions.
The aim of this review is to discuss (basing on the literature reports as well as on our own research results and experience) ways of activation of binding mixtures containing high and very high amount of fly ash. Some traditional and new trends in the activation of binders basing on fly ash were described. Effectiveness and mechanisms of the selected activating processes depending on the amount and type of fly ash were discussed. Special emphasis was put on indication usefulness of calorimetry and thermal analysis for such studies. These methods are frequently used in case of studies of hydration processes of cement in the presence of different additives (e.g. [37-42]). They are also useful in case of investigations of hydration/activation processes of high and very high volume fly ash mixtures.

\section{Early hydration of non-activated mixtures containing high and very high amount of fly ash}

Fly ash is a fine-grained by-product of power industry. Its properties depend on several factors such as: type of combusted solid fuel (e.g. fly ash from combustion of hard coal, brown coal, rice husk ash), technology of combustion (e.g. pulverised combustion, fluidised combustion), technology of off-gasses desulfurisation. Fly ash reactivity in cement or in fly ash-lime pastes is low at room temperature and strictly depends on its properties, amount and conditions of hardening [21, 38, 43-45]. This by-product can react with $\mathrm{Ca}(\mathrm{OH})_{2}$ (pozzolanic reaction), which is formed during hydration of cement or it may be introduced as an additional component of mixture. Fly ash containing sufficient amount of calcium and/or sulphate components exhibits some self-cementing properties in the presence of water [45-47]. Low-calcium fly ash cannot harden in the presence of water.

Different ways of fly ash-cement interactions may be considered contributing to the development of properties of final composite. In general, fine grains of fly ash may act as nucleation centres for the precipitated products of hydration, thus fly ash may accelerate hydration of cement. Pozzolanic reaction between $\mathrm{Ca}(\mathrm{OH})_{2}$ and active silica and alumina from fly ash contributes to the formation of additional amount of hydrated calcium silicates (the socalled $\mathrm{C}-\mathrm{S}-\mathrm{H}$ phase) and calcium aluminates. Non-reacted grains may act as microfillers.

In general, in mixtures containing high amount of fly ash and low amount of cement, these two components influence each other the reactivity. Fine grains of fly ash may accelerate hydration of cement, while the presence of cement activates reactivity of fly ash by progressive increase in the $\mathrm{pH}$, delivery of $\mathrm{Ca}(\mathrm{OH})_{2}$ for pozzolanic reaction as well as improvement in the dissolution of grains 


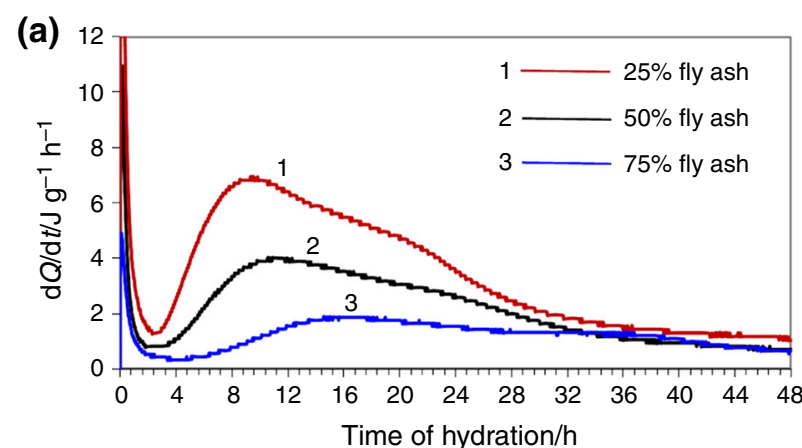

(b)

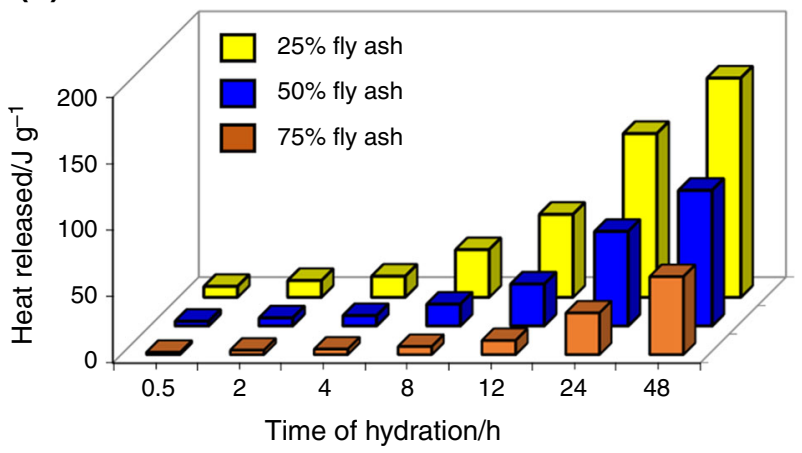

Fig. 3 Exemplary curves of heat release rate (a) and total heat released (b) of low-calcium fly ash-Portland cement mixtures during $48 \mathrm{~h}$ of hydration with water (fly ash from pulverised combustion of hard coal, water/binder $=0.5$, initial temperature $25^{\circ} \mathrm{C}$, BMR calorimeter) (data for 50\% replacement according to [49], binder $=$ cement + fly ash)

of fly ash by increase in temperature of the mixture (exothermal process of cement hydration) [48]. However, in case of high amount of fly ash in fly ash-cement mixtures dilution effect predominates during the early stages of hardening. Firstly, fly ash needs adequate $\mathrm{pH}$ of solution and $\mathrm{Ca}(\mathrm{OH})_{2}$ for exhibition of its pozzolanic properties. Due to this fact, the first step must be hydration of cement and production of $\mathrm{Ca}(\mathrm{OH})_{2}$. Thus, early hydration periods depend on cement which is in the mixture in low amount. Secondly, fly ash needs some time for pozzolanic reaction. The reaction is slow in ambient temperature, because of low solubility of aluminosilicate grains at $\mathrm{pH}$ provided by hydration of cement. Thus, hydration processes and formation of solid products go significantly slowly in fly ashcement mixtures compared to hydration of Portland cement $[21,49,50]$. Exemplary, it is clearly seen in Fig. 3, which presents calorimetric results for hydration of mixtures containing different amount of conventional low-calcium fly ash from combustion of hard coal. ${ }^{1}$ In general, shapes of

\footnotetext{
${ }^{1}$ Commercially available Portland cement CEM I 32.5R was used in all measurements results of which were presented in Figs. 3, 4, 5, 6, 8 and 9, average chemical composition (the main components) of cement [mass\%]: $\mathrm{SiO}_{2}$ 20.1, $\mathrm{Al}_{2} \mathrm{O}_{3} 4.4, \mathrm{Fe}_{2} \mathrm{O}_{3}$ 2.3, $\mathrm{CaO}$ 62.6, $\mathrm{SO}_{3}$ 3.2, $\mathrm{Na}_{2} \mathrm{O}+\mathrm{K}_{2} \mathrm{O}$ 1.2, $\mathrm{MgO} 2.7$, average chemical composition (the main components) of fly ash [mass\%]: $\mathrm{SiO}_{2} 50, \mathrm{Al}_{2} \mathrm{O}_{3} 20, \mathrm{Fe}_{2} \mathrm{O}_{3} 7, \mathrm{CaO} 5$,
}

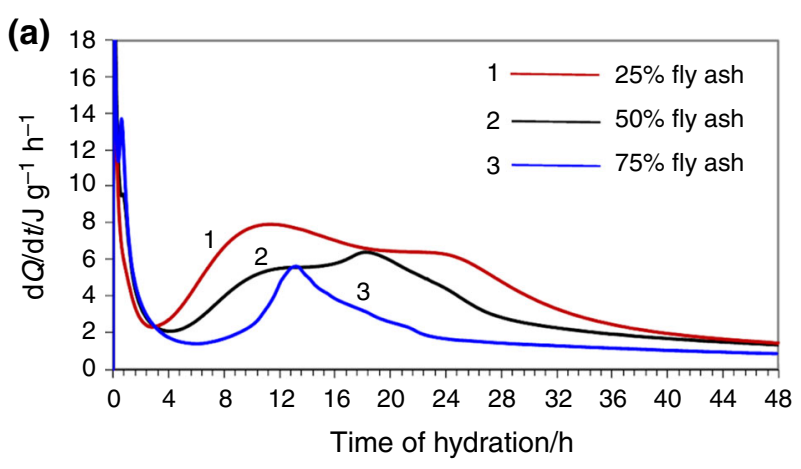

(b)

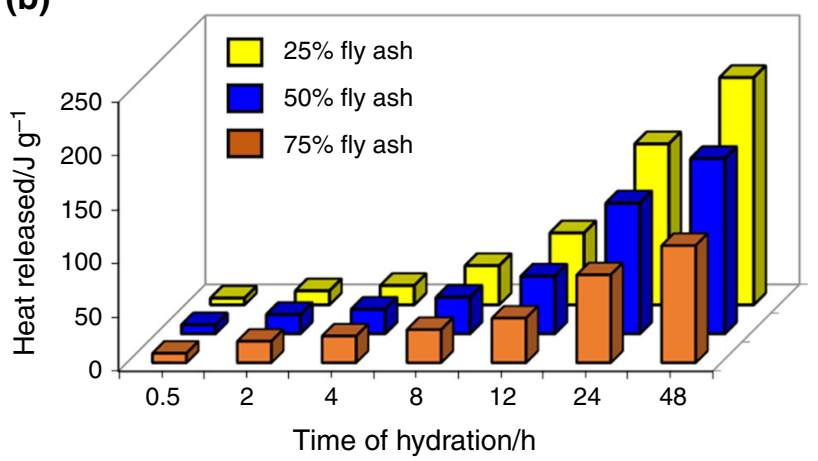

Fig. 4 Exemplary curves of heat release rate (a) and total heat released (b) of calcium fly ash-Portland cement mixtures during $48 \mathrm{~h}$ of hydration with water (fly ash from pulverised combustion of brown coal, water/binder $=0.5$, initial temperature $25^{\circ} \mathrm{C}$, BMR calorimeter) (Chemical composition (the main components) of fly ash [mass\%]: $\mathrm{SiO}_{2}$ 61.7, $\mathrm{Al}_{2} \mathrm{O}_{3}$ 11.3, $\mathrm{Fe}_{2} \mathrm{O}_{3}$ 2.7, $\mathrm{CaO}$ 17.1, $\mathrm{SO}_{3}$ 1.7, $\mathrm{Na}_{2} \mathrm{O}+\mathrm{K}_{2} \mathrm{O}<0.5, \mathrm{MgO} 1$, crystalline components of fly ash: quartz, anhydrite, anorthite, gehlenite, haematite, calcite, free $\mathrm{CaO}$ [60], the same fly ash was used in case of measurements results of which are presented in Figs. 5 and 6. Data for $75 \%$ replacement according to [49])

calorimetric curves of the rate of heat release are similar to those for Portland cement presented, e.g. in [51, 52]. There are several characteristic periods on these curves: quick release of heat after addition of water (wetting of grains, dissolution of some components), then induction period (heat release is inhibited) followed by re-growth of heat release rate (precipitation of products of hydration) and, after reaching maximum, fall of rate of heat release (the processes undergo in solid state). It is visible that the higher the replacement level is, the longer induction period, the lower intensity of the effect related to precipitation of products and the lower total heat released. It indicates that time of start of setting is the longer and early compressive strength is the lower together with increasing amount of fly ash and simultaneously decreasing amount of cement. In case of such mixtures, Portland cement is mainly responsible for early hydration and heat emission despite some

Footnote 1 continued

$\mathrm{SO}_{3} 1, \mathrm{Na}_{2} \mathrm{O}+\mathrm{K}_{2} \mathrm{O} 3, \mathrm{MgO} 3$, crystalline components of fly ash: mullite, quartz, anorthite, hematite [20,60]. 

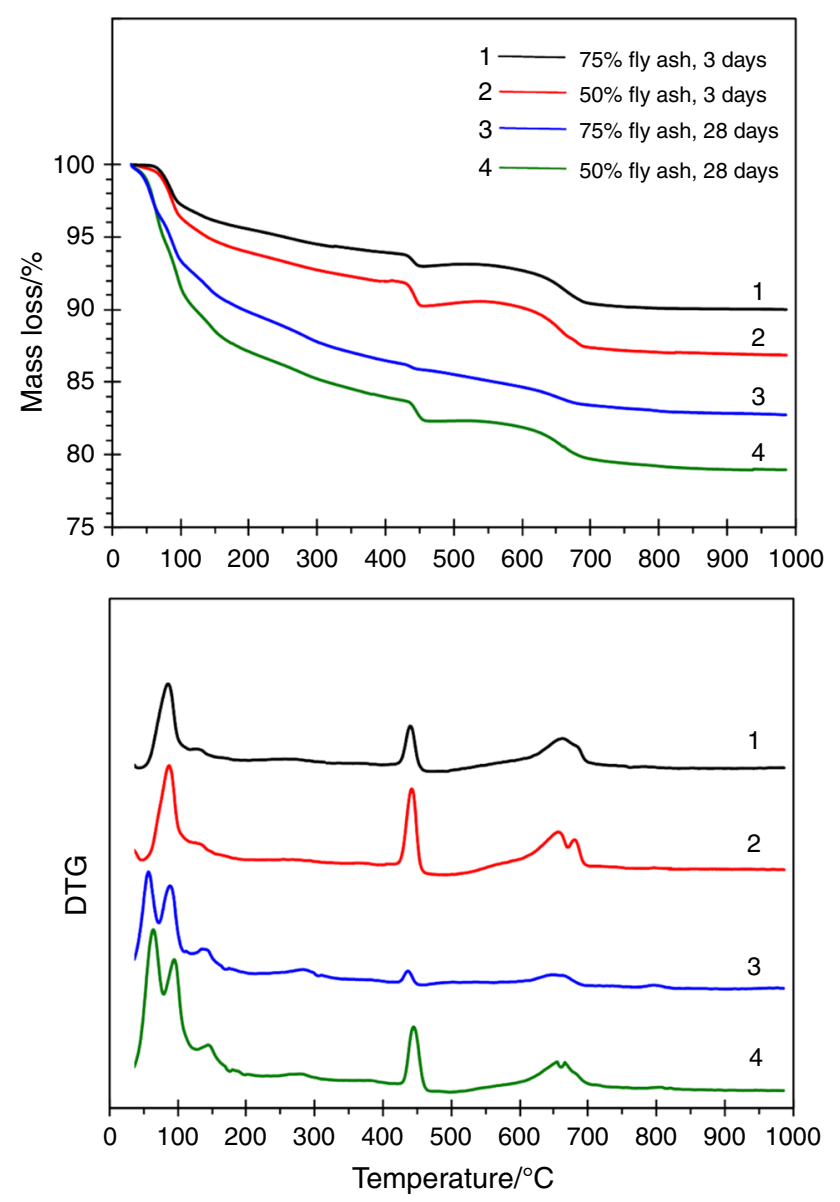

Fig. 5 Exemplary TG and DTG curves for fly ash-cement pastes containing 50 or $75 \%$ of calcium fly ash from brown coal combustion, $3 \mathrm{rd}$ and 28th day of hydration (water/binder $=0.5$, hardening at ambient temperature, inhibition of hydration by the use of acetone, apparatus: SDT 2960 Thermoanalyser (TA Instruments), heating rate $10{ }^{\circ} \mathrm{C} \mathrm{min}^{-1}$, nitrogen atmosphere)

acceleration action of fly ash grains regarding to cement hydration [49]. This conclusion is consistent with the information given in $[38,53,54]$ according to which the pozzolanic reaction between fly ash and $\mathrm{Ca}(\mathrm{OH})_{2}$ starts from about 3rd day of hydration or even after 7 days. Similar results of calorimetric studies of early hydration of mixtures containing high amount of low-calcium fly ash were presented in several publications, e.g. $[38,50]$. There is also confirmation about slow reaction of fly ash with $\mathrm{Ca}(\mathrm{OH})_{2}$ and the fact that during early days, hydration of cement dominates reaction of mixture containing high amount of Class $\mathrm{F}$ fly ash and is mainly responsible for setting, hardening and development of early compressive strength [36]. The relationship showing that the higher is the content of fly ash introduced as Portland cement replacement, the greater is reduction in compressive strength repeatedly confirmed in studies by various authors, e.g. $[55,56]$. Such inconveniences related to mixtures containing high and very high amount of low-calcium
Class $\mathrm{F}$ fly ash are caused, inter alia, by inadequate amount of $\mathrm{Ca}(\mathrm{OH})_{2}$ produced during hydration of small amount of cement. Calculations made by Myadraboina et al. [57] showed that $50 \%$ and higher of cement replacement by fly ash results in insufficient amount of $\mathrm{Ca}(\mathrm{OH})_{2}$. Thus, one can conclude that mixtures containing very high amount of low-calcium fly ash need additional amount of calcium component to develop fly ash activity fully. However, it should also be emphasised in this place that lowering the amount of released heat with the replacement of cement by fly ash is favourable in case of massive concrete. Increasing temperature inside the concrete slab as a result of exothermal hydration processes may cause cracks and reduction in durability. Therefore, binders containing high amount of fly ash may be favourable in case of massive concretes. Wang et al. [31] proposed to use high volume fly ash $(45 \%)$ concrete for a concrete foundation slab. They found that the temperature rise in concrete decreased and cracking risk of such massive concrete was reduced. Moreover, they showed that proper design of concrete mixture, taking into account water to binder ratio, the amount of fly ash, amount of binder and type of cement enabled the gain of the expected level of 60-day compressive strength.

Investigations of microstructure of pastes containing high and very high amount of low-calcium fly ash after 6 months of hydration showed the presence of $\mathrm{C}-\mathrm{S}-\mathrm{H}$ phase coexisting with hydrated gehlenite $\left(\mathrm{C}_{2} \mathrm{ASH}_{8}{ }^{2}\right.$, typical product of reaction of pozzolanic material rich in aluminates) and moreover small amount of $\mathrm{Ca}(\mathrm{OH})_{2}$ and small amount of ettringite. $\mathrm{C}-\mathrm{S}-\mathrm{H}(\mathrm{I})$ formed in such systems exhibited lower $\mathrm{Ca} / \mathrm{Si}$ ratio as compared to $\mathrm{C}-\mathrm{S}-\mathrm{H}$ formed in pure cement paste [58].

In case of fly ash containing higher amount of calcium components (Class C fly ash), shape of calorimetric curve is different as compared with results for low-calcium fly ash-cement mixtures (Fig. 4). This type of fly ash exhibits some self-cementing properties. It means that such kind of fly ash to some extent is able to form hardened structure in the presence of water without introducing additional amount of $\mathrm{Ca}(\mathrm{OH})_{2}$; however, its activity and properties after reaction with water are significantly lower than in case of Portland cement. Chemical and phase composition of calcium fly ash is usually more complicated compared to compositions of siliceous fly ash. Among others, calcium ingredients may be present in form of different chemical compounds, such as $\mathrm{CaO}, \mathrm{CaCO}_{3}, \mathrm{CaSO}_{4}$, gehlenite, anorthite, etc. They exhibit different ability to react in the presence of water; moreover, the presence of high amount of free $\mathrm{CaO}$ is unfavourable [59]. However, due to its

\footnotetext{
${ }^{2}$ Abbreviations used in cement chemistry: $\mathrm{C}-\mathrm{CaO}, \mathrm{S}-\mathrm{SiO}_{2}, \mathrm{H}-$ $\mathrm{H}_{2} \mathrm{O}, \mathrm{N}-\mathrm{Na}_{2} \mathrm{O}, \mathrm{A}-\mathrm{Al}_{2} \mathrm{O}_{3}$.
} 
binding properties, calcium fly ash may be perspective if it is considered as a substitute of high amount of cement in binding mixture. But such utilisation of calcium fly ash needs further intense studies.

Different contribution of fly ash containing calcium components (from pulverised combustion of brown coal), compared to low-calcium fly ash (from pulverised combustion of hard coal), to the early hydration of blended mixtures is shown in exemplary results of our investigations presented in Fig. 4. It is evident that the more intense the first wetting period is, the higher the amount of calcium fly ash is in the mixture. As the ash content increases, the induction period is longer, similarly as is the case of mixture containing low-calcium fly ash. However, after the induction period relative intense effect connected with precipitation of hydrated products appears. Another difference is the presence of additional thermal effect. It is intense and appears faster when greater the amount of fly ash is.

Figure 5 presents examples of our results of TG/DTG investigations performed for high and very high volume fly ash pastes composed of calcium fly ash from combustion of brown coal. It is evident that shapes of TG/DTG curves resemble those for Portland cement paste. There are three main mass losses on TG curves:

- up to about $425{ }^{\circ} \mathrm{C}$-dehydration of water bound in products of cement hydration as well as pozzolanic reaction (ettringite, $\mathrm{C}-\mathrm{S}-\mathrm{H}$ phase, $\mathrm{C}-\mathrm{A}-\mathrm{S}-\mathrm{H}, \mathrm{C}-\mathrm{A}-\mathrm{H}$ phases),

- from about 425 to $480{ }^{\circ} \mathrm{C}$-loss of water from $\mathrm{Ca}(\mathrm{OH})_{2}$ decomposition,

- from about 550 to $700{ }^{\circ} \mathrm{C}$-decomposition of carbonates.

The main mass loss is caused by endothermic processes of release of water: dehydration of hydrated forms and dehydroxylation of $\mathrm{Ca}(\mathrm{OH})_{2}$ (Figs. 5, 6). Release of water from individual hydrates occurs at a broad temperature range. That is why, dehydration processes overlap. For example, according to data given by authors of [61], synthesised C-S-H phase can dehydrate up to about $600{ }^{\circ} \mathrm{C}$, while the main mass loss occurs up to $200{ }^{\circ} \mathrm{C}$ (extremum on DTG at about $100{ }^{\circ} \mathrm{C}$ ). The observed effects in Figs. 5 and 6 up to about $125{ }^{\circ} \mathrm{C}$ can be related to the presence of ettringite and $\mathrm{C}-\mathrm{S}-\mathrm{H}$ phase in sample as well as loosely bound water in gel. The effects occurring at higher temperature range are mainly connected with calcium aluminates and aluminosilicates ( $\mathrm{C}-\mathrm{A}-\mathrm{H}$ and $\mathrm{C}-\mathrm{A}-\mathrm{S}-\mathrm{H}$ phases), $\mathrm{AF}_{\mathrm{m}}$ phase as well as carboaluminates.

It can be seen that the mass loss up to about $425^{\circ} \mathrm{C}$ increases with hydration time. It is a proof that hydration reactions take place and solid products, such as $\mathrm{C}-\mathrm{S}-\mathrm{H}$ phase and hydrated aluminate, sulfoaluminate and

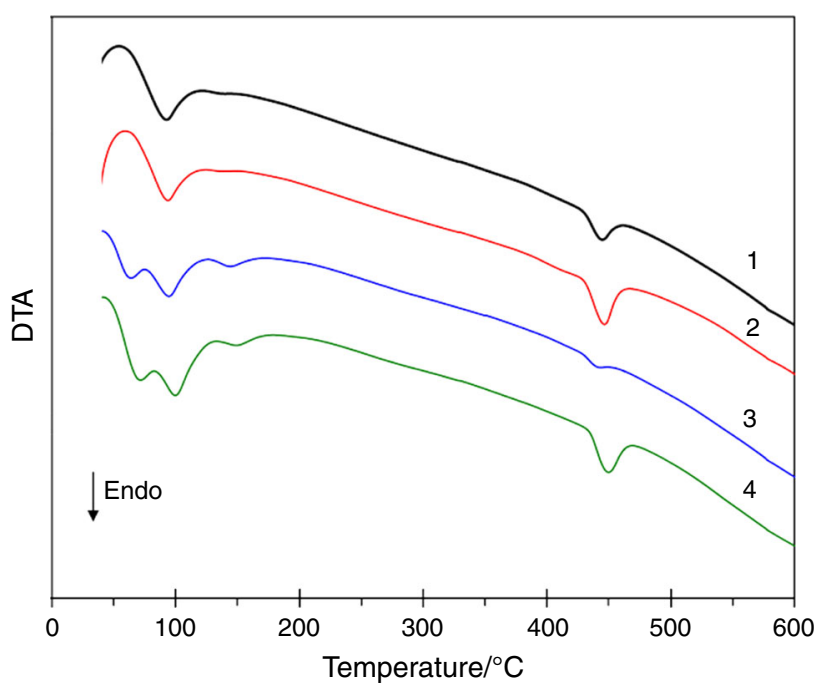

Fig. 6 Exemplary DTA curves for fly ash-cement pastes at temperature region of dehydration processes (legend and conditions of measurements are described in Fig. 5)

aluminosilicate phases, are precipitated. The hydrated aluminate phases are mainly formed after 3 days of hydration which is indicated by effects on DTG curves at about 120 and $280{ }^{\circ} \mathrm{C}$ visible on 28th day. The amount of $\mathrm{Ca}(\mathrm{OH})_{2}$ is decreased during the time of hydration-it proves pozzolanic reaction. In the case of $50 \%$ replacement of cement, this reduction in $\mathrm{Ca}(\mathrm{OH})_{2}$ content is not high. It indicates that hydration of cement takes place, and it ensures $\mathrm{Ca}(\mathrm{OH})_{2}$ for pozzolanic reaction with fly ash. It enables to develop fly ash reactivity also after 28th day of hydration. On the contrary, in the case of $75 \%$ replacement, $\mathrm{Ca}(\mathrm{OH})_{2}$ is almost not visible on 28th day. It shows that at such high content of fly ash, the amount of $\mathrm{Ca}(\mathrm{OH})_{2}$ is insufficient, despite the fact that this fly ash contains calcium components. It is the effect of the presence of different forms of calcium components in this fly ash [60]; some of them exhibit low activity. Comparing with TG/ DTG results obtained for fly ash-cement paste composed with $80 \%$ low-calcium fly ash [20], one can state that also in case of this kind of cement replacement, $\mathrm{Ca}(\mathrm{OH})_{2}$ was almost completely consumed during 28 days of hydration.

Yazıc1 [56] investigated high volume fly ash concretes containing $60 \%$ of Class $\mathrm{C}$ fly ash as cement replacement. They registered decreasing of compressive strength as compared with reference Portland cement concrete through all the time of investigation, i.e. till 90th day of hydration. It indicated that calcium fly ash used in high amount did not fully replace cement in these compositions. Dakhane et al. [62] investigated mixtures containing higher amount; it is $70 \%$ of Class C fly ash. They confirm acceleration of setting in the presence of Class $\mathrm{C}$ fly ash compared to samples composed of Class F fly ash. Compressive strength, both early and after 28 days, for binders 
containing calcium fly ash was also higher than for those with Class F fly ash and microstructure was more compact [62]. Güneyisi and Gesoğlu [63] show that in case of high replacement (60 and $80 \%$ ) of cement by Class $\mathrm{C}$ fly ash rapid setting occurs and initial time of setting is reduced. In case of Class F fly ash, such phenomenon is not observed because this kind of fly ash does not contain sufficient amount of active calcium compounds. Early compressive strength of composite containing high volume replacement of cement by fly ash was reduced, especially in case of $80 \%$ fly ash content. However, starting from 28th day of hydration, compressive strength of mixtures containing $80 \%$ of calcium fly ash was higher than for adequate sample with Class F fly ash [63]. Beneficial effect of using of $50 \%$ fly ash (as cement replacement) containing calcium as well as sulphate components on compressive strength of concrete compared to results for concrete performed with low-calcium fly ash was confirmed also in our investigations [64]. However, in case of using high amount of fly ash containing increased content of sulphates and calcium components serious risk connected with durability appears. In such systems delayed ettringite may arise. Its formation in hardened structure may cause micro-stresses and as a result deterioration of durability of fly ash-cement composite. Thus, this direction of utilisation of such fly ash needs especially intense investigations on hardening mechanism, phase and crystal composition of matrix and long-term properties of final composite.

The kind of fly ash used as replacement of cement is key but not the only factor influencing properties of fly ashcement composites. In general, one can affirm that the kind of fly ash (or other aluminosilicate material) used as cement substitute, its amount, the amount of water, the presence of plastificating admixtures, conditions of curing and hardening as well as time influence hydration processes (kinetics especially) and properties of final composite. High and very high volume fly ash mixtures are more sensitive to the curing conditions compared to reference sample composed of Portland cement [27, 65].

Summarising, utilisation of high amount of fly ash as cement replacement is favourable especially from ecological point of view. However, it is not a surprise that such compositions will show deterioration of some properties, setting time and early compressive strength especially. One of reasons is insufficient amount of $\mathrm{Ca}(\mathrm{OH})_{2}$. It seems to be reasonable that solution of this problem may be utilisation of Class C fly ash containing calcium components and exhibiting better reactivity compared to Class F fly ash. However, fly ashes containing calcium components are more diverse in composition and properties. Thus, their influence on features of final material may also differ. Moreover, calcium compounds may be present in fly ash in various forms differing in activity and possibility to create desirable products. Utilisation of such kind of fly ash in high and very high amount in binding materials requires special care and in-depth researches.

\section{Mechanical activation}

Mechanical activation can increase reactivity of different pozzolanic additives including fly ash [66-68]. This activation takes place through high-energy grinding. During such mechanical treatment of fly ash, its surface area is increased as well as physicochemical changes on the surface of grains and in bulk may occur [69, 70]. Morphology of fly ash grains changes, its spherical particles of different sizes are broken during the grinding process and they become smaller and irregular [71]. Different kinds of milling equipments (ball mills) may be used for this purpose $[69,70,72]$. Effectiveness of mechanical activation depends on conditions of milling process; however, chemical composition of activated material is also essential. The main factors influencing mechanical activation of fly ash are following: speed of rotation, size and amount of milling balls used, the presence of liquid medium and its type, time of grinding, etc. [70]. In case of mild conditions of grinding, material undergoes mainly homogenisation, while changes of grains are not significant. During more aggressive grinding, surface of grains breaks down. Finally, grains become smaller reaching the desired size and surface area. Exemplary results of our investigations showing changes in fly ash subjected to mechanical activation are presented in Fig. 7. The results confirm that fly ash from conventional combustion of coal is composed from spherical grains of different diameters. Grinding causes mainly fragmentation of bigger grains leaving the finer ones almost intact. The average grain diameter decreases as a result of mechanical activation.

Fly ash grains diameter below $45 \mu \mathrm{m}$ are beneficial, and using such fly ash as cement replacement can give higher strength results than originally fly ash composed of fractions of different size [73]. Thus, grinding is often proceeded to obtain such particle diameter, e.g. in studies described in [19]. However, it should be emphasised in this place that fine fraction of fly ash may be obtained not only during mechanical activation, but also as a result of classification during which more reactive, fine fraction rich in glassy components is separated [69, 72, 74]. In general, the smaller the particle size, the higher the hydration activity of fly ash is [57, 75]. Thus, grinding process aimed in obtainment of fly ash of even more fragmentation is also desirable. Ultrafine fly ash exhibiting an average particle size of less than $10 \mu \mathrm{m}$ may be produced during highenergy mechanical milling with the use of grinding aids to improve grinding efficiency $[75,76]$. 
Fig. 7 General view (magnification $\times 1000)$ of particles of raw fly ash and fly ash which was subjected to grinding by $1 \mathrm{~h}$ in laboratory planetary ball mill (a) and granulometric composition (b, c)

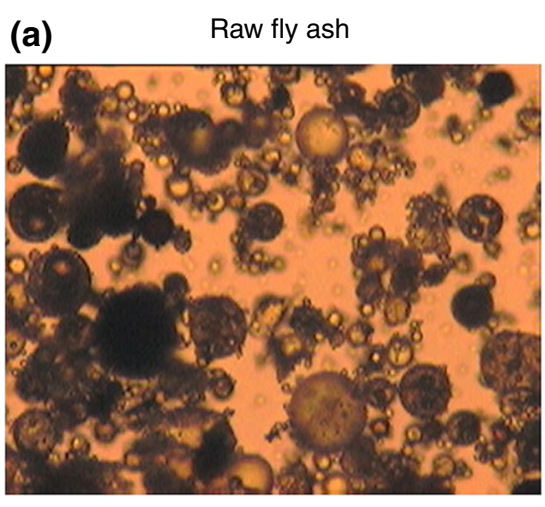

$50 \mu \mathrm{m}$
Grinded fly ash

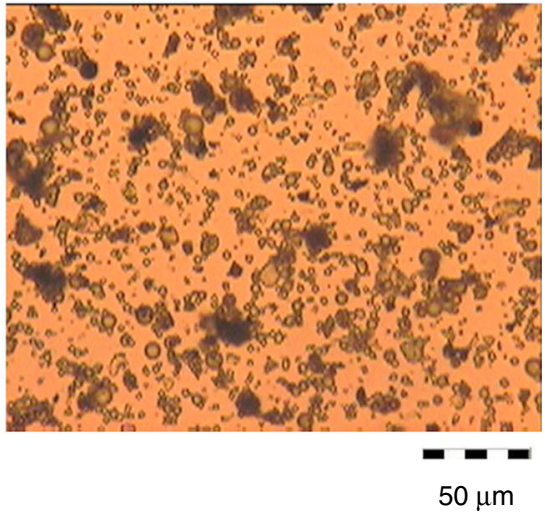

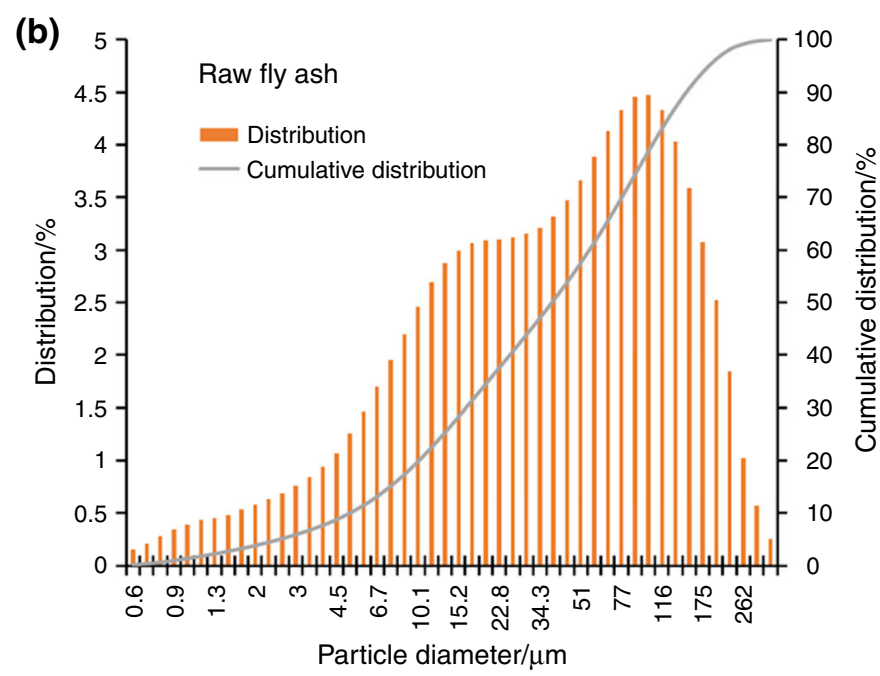

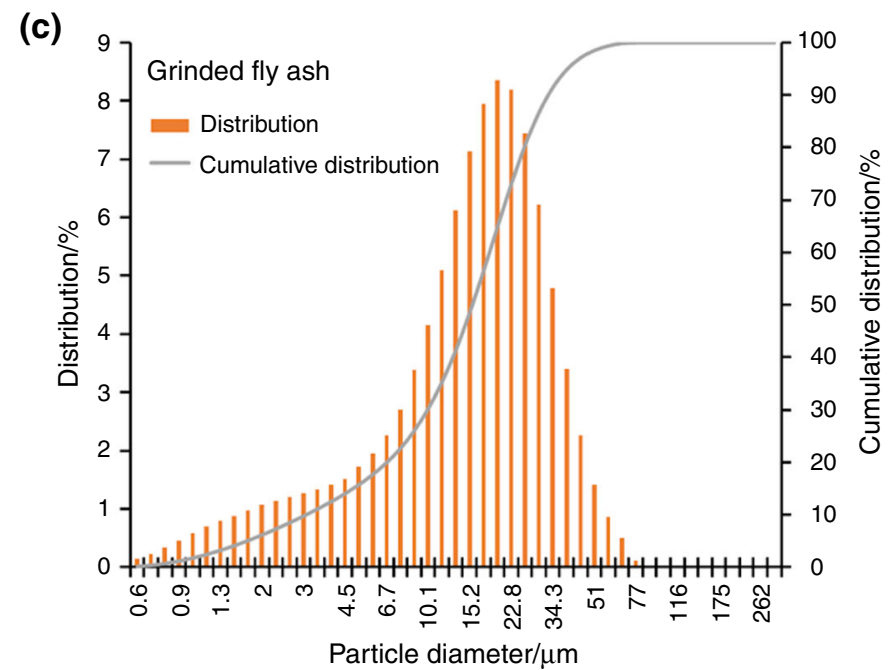

Depending on the conditions of milling, not only reduction in grains size and increase in surface area take place. Chemical and phase changes also occur, such as structural defects and rearrangements as well as phase transformations [69]. An increase in the level of amorphisation of the sample is expected; however, some new crystal phases during the mechanical activation may be also formed, e.g. as a result of energy provided by grinding 

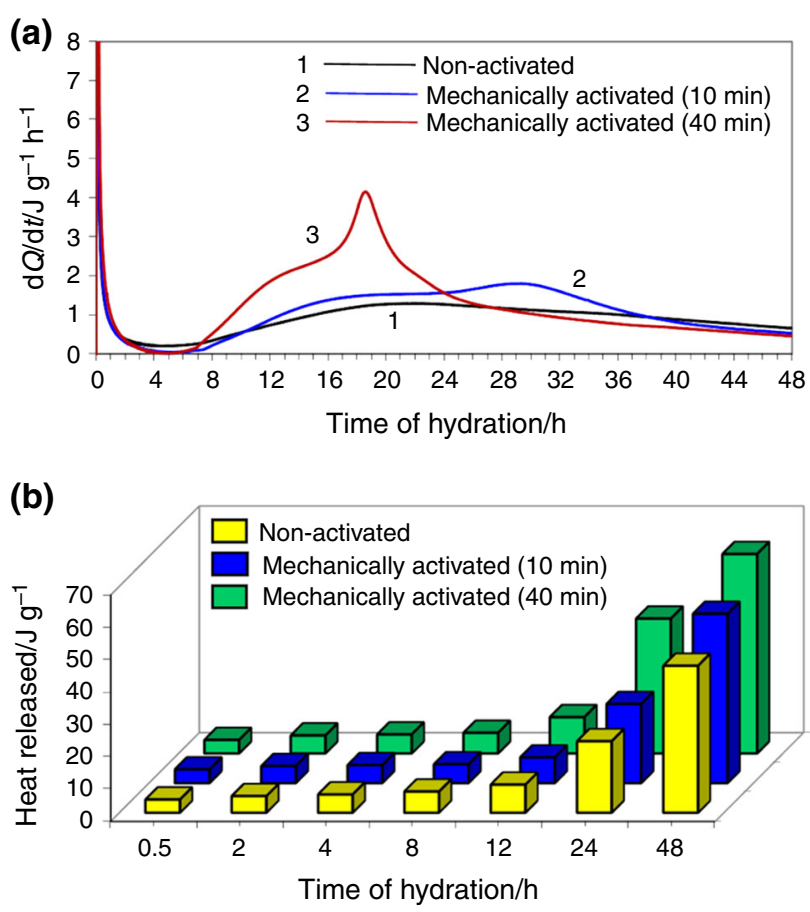

Fig. 8 Exemplary curves of heat release rate (a) and total heat released (b) for mechanically activated mixture containing $80 \%$ of fly ash and $20 \%$ of Portland cement (fly ash from pulverised combustion of hard coal, intergrinding of dry components for 10 or $40 \mathrm{~min}$. before water adding, water/binder $=0.5$, initial temperature of hydration $25{ }^{\circ} \mathrm{C}$, BMR calorimeter) (average chemical composition (the main components) of fly ash [mass\%]: $\mathrm{SiO}_{2} 54.2, \mathrm{Al}_{2} \mathrm{O}_{3} 28.9, \mathrm{Fe}_{2} \mathrm{O}_{3}$ 5.2, $\mathrm{CaO} 2.3, \mathrm{SO}_{3} 0.2, \mathrm{Na}_{2} \mathrm{O}+\mathrm{K}_{2} \mathrm{O} 2.6, \mathrm{MgO} 1.1$, the same fly ash was used in case of measurements results of which are presented in Fig. 9)

process [71]. Li et al. [77] show that long ball-milling treatment of fly ash results in reduction in crystallite size, loss of crystallinity as a result and an increase in amorphous phases. They also affirmed changes undergoing in structure of pores and in functional groups, while the time of milling was an important factor influencing these modifications.

All the alterations being results of mechanical activation of fly ash influence its reactivity in fly ash-cement system. Mechanical activation can improve the dissolution process and reactivity of fly ash by allowing better contact between reagents as a result of increase in specific surface area of the grains, their structural defects and higher amorphisation [71]. In general, fly ash fineness and specific gravity increase with grinding time, while the greater the fly ash reactivity is, the finer fly ash grains are [11].

Modifications of fly ash/binder properties by mechanical activation cause that mechanism of hydration reaction may be changed as it is presented in Fig. 8 showing exemplary results of our investigations. In these studies, mechanical activation consisting of grinding together (intergrinding) fly ash $(80 \%)$ and cement $(20 \%)$ during 10 or $40 \mathrm{~min}$. in laboratory planetary ball mill was used. In such conditions, both the components undergo activation. As a result, period of precipitation of products of hydration was more intense and additional exothermic effect appeared (more intense in case of longer grinding). It is, probably, the effect of hydration of aluminates which were more available after grinding. Mechanical activation did not influence significantly duration of induction period in this case. Thus, one can expect that mechanical activation did not influence significantly time of start of setting in discussed case [49]. However, next period on calorimetric curve has visible higher intensity. All of these changes are related to increasing rate of hydration; thus, it indicates shorter time of the end of setting. Similar results for mixtures containing $70 \%$ of grinded fly ash were presented in [74].

Enhancement of reactivity of fly ash, easier dissolution of its components and better contact of reagents cause that some properties of fly ash-cement mixtures can be improved. A lot of research reports proved that it is possible to enhance compressive strength of mixtures containing high amount of fly ash by mechanical activation. There are publications discussing effectiveness of this type of activation depending on different factors, such as the kind of fly ash, the way of grinding of dry constituents (separately or intergrinding), using grinding aids, time of grinding, as well as time and temperature of hardening of composites performed with mechanically activated materials, etc. $[11,65,69,73,74,78]$. For example, Kumar et al. [69] concluded that $50-60 \%$ of mechanically activated fly ash can be used as clinker replacement and such blended cement exhibits compressive strength and other properties comparable to commercial cement. They found reduction in induction period in case of mechanically activated mixture containing clinker and $50 \%$ of fly ash. Authors of [11] reported that intergrinding of blended cement components may give significantly better results of compressive strength than separately mechanical treatment of clinker and fly ash. It may be the effect of better homogeneity. The advantages of intergrinding on separate grinding of the components were also reported by other researchers [73]. Jaturapitakkul et al. [79] received very fine fly ash of average particle size below $4.0 \mu \mathrm{m}$ by grinding coarse fraction of fly ash. They demonstrated that concrete containing this ground fly ash in amount of 50\% as cement replacement exhibited compressive strength similar to results for ordinary Portland cement concrete. Supit et al. [76] investigated high and very high volume fly ash mixtures (40-70\% of Class F fly ash) modified by the presence of $8 \%$ of ultrafine fly ash. They found that samples with addition of ultrafine fly ash exhibit enhancement compressive strength compared to those composed without this very fine component. Beneficial results for samples containing ultrafine fly ash are probably an effect of better effectiveness in consuming of $\mathrm{Ca}(\mathrm{OH})_{2}$ in pozzolanic 
reaction and densification of the structure. However, despite an enhancement effect of ultrafine fly ash, 28-day compressive strength of mortars containing very high volume fly ash binder was more than three times lower as compared for reference Portland cement mortar [76]. Similarly, Roychand et al. [80] showed that $80 \%$ replacement of Portland cement by ultrafine fly ash results in significant reduction in compressive strength as compared to Portland cement reference mortar. For this reason, the authors of [80] proposed partial replacement of this fly ash by other components.

Summarising, it is possible to enhance reactivity of fly ash-cement mixture using mechanical activation. In case of mechanical treatment of both main constituents of the binder, it is beneficial to use intergrinding instead of separate grinding. Physical and chemical changes of solid components of the binder strictly depend on conditions of mechanical activation and time. It is possible to improve some properties of composites containing high and very high amount of fly ash and in this way extend possibilities of their use. However, in case of very high volume fly ash mixtures, mechanical activation may be insufficient to improve setting time and compressive strength satisfactory. It is because grinding process does not change the amount of hydraulic components which are necessary to form solid structure. In this case, activation may be insufficient. Thus, in such case, another methods of activation of the system also connected with mechanical treatment of dry mix constituents should be considered.

\section{Activation by exchanging part of aluminosilicate component by more reactive material}

Exchanging of part of aluminosilicate component of binding mixture by more reactive material aims quicker development and improvement in early properties of final composites. One can distinguish two main possibilities of this method of activation: exchanging of cement or exchanging of fly ash by other components. In the first case, one can consider total or partial replacement of cement by more rapid set one. In this way, acceleration of setting and hardening and better early compressive strength may be expected. In the second case, replacement of a part of fly ash by more reactive pozzolana causes quicker reaction with $\mathrm{Ca}(\mathrm{OH})_{2}$ and formation of binding phases.

\section{More rapid set cement or additional amount of $\mathrm{Ca}(\mathrm{OH})_{2}$}

Bentz and Ferraris [81] investigated hydration of mixtures containing $50 \%$ of fly ash and $50 \%$ of cement which was partially replaced by rapid set cement. They concluded that the presence of rapid set cement reduces significantly initial setting time of the mixture. Promising strength results were obtained by McCarthy and Dhir [82], who used rapidhardening Portland cement or low-energy clinker in place of typical Portland cement. However, in case of these investigations [82] the amount of cement replacement by Class F fly ash was only $45 \%$. It was proved in our previous work [83] that in case of high and very high amount of fly ash in the mixture ( 40 or $80 \%$ by mass) some improvement can be achieved by replacing the used Portland cement by a higher class Portland cement. It was observed that in the presence of cement of higher class induction period on calorimetric curve was shorter and precipitation of products during the next period was more intense; thus, shorter time of initial setting may be expected.

In mixtures containing fly ash and cement, $\mathrm{Ca}(\mathrm{OH})_{2}$ arising during hydration of cement activates fly ash. For this reason, introduction of additional amount of $\mathrm{Ca}(\mathrm{OH})_{2}$ or $\mathrm{CaO}$ into fly ash-cement mixtures may be considered as one of methods of activation improving compressive strength and durability of final composite. Some problems with the use of $\mathrm{Ca}(\mathrm{OH})_{2}$ for this purpose may result from low solubility of $\mathrm{Ca}(\mathrm{OH})_{2}$ as well as some retardation of hydration of cement. Thus, ensuring good homogeneity of mixture is especially important. Moreover, $\mathrm{Ca}(\mathrm{OH})_{2}$ may be contaminated by $\mathrm{CaCO}_{3}$ which decreases its activity. These may be the reasons of different literature reports concerning efficiency of this activator in high and very high volume fly ash mixtures. Thus, activation of fly ash by the presence of additional amount of $\mathrm{Ca}(\mathrm{OH})_{2}$ may not be revealed significantly at early periods of hydration especially in case of very high volume fly ash binders and low amount of $\mathrm{Ca}(\mathrm{OH})_{2}$. It was proved in our calorimetric measurements [83]. It was shown that introduction of $2 \%$ of $\mathrm{Ca}(\mathrm{OH})_{2}$ into very high volume fly ash mixture did not influence kinetics of early hydration significantly.

Velandia et al. [84] investigated reactivity of different high losses on ignition fly ashes (used as $50 \%$ of cement replacement) in the presence of lime and quicklime. They showed that the properties of fly ash, especially content of amorphous phases and grain size, as well as the amount and the type of used activator influence reactivity of fly ash. In general, the authors found that influence of quicklime and lime on the compressive strength is rather little; however, in some cases early compressive strength was improved. Barbhuiya et al. [54] showed that introduction of 5\% of hydrated lime results in improvement in early (3-day) and later (28-day) compressive strength of sample containing $50 \%$ of low-calcium fly ash. Results presented in [85] showed that compressive strength of very high volume fly ash mixture (about 70\%) is not influenced by additional amount of $\mathrm{Ca}(\mathrm{OH})_{2}$ till 7th day of hydration. It indicates 
that the presence of $\mathrm{Ca}(\mathrm{OH})_{2}$ slightly improves fly ash reactivity at early stages but provides component for the pozzolanic reaction at later periods. Studies of content of $\mathrm{Ca}(\mathrm{OH})_{2}$, based on TG/DTG results, have allowed the authors to state that the reactivity of fly ash is enhancement with addition of the hydroxide and as result of it 28-day compressive strength is improved. Similarly, Lorca et al. [86] presented that introduction of $\mathrm{Ca}(\mathrm{OH})_{2}$ into concrete containing 50 or $70 \%$ of low-calcium fly ash as cement replacement results in improvement in compressive strength starting from 7 th day of hardening. Thermal analysis after 1 year of hardening revealed the absence of $\mathrm{Ca}(\mathrm{OH})_{2}$ in high and very high volume fly ash concretes. Several peaks on DTG curves allowed the authors to identify some products of hydration and pozzolanic reaction: $\mathrm{C}-\mathrm{S}-\mathrm{H}$ phase, ettringite and hydrated calcium aluminosilicate type of gehlenite.

\section{Silica and aluminosilicate pozzolanic materials}

Another possibility to improve early as well as later properties of binding mixtures containing high and very high amount of fly ash is introduction into the system small amount of pozzolanic materials exhibiting better reactivity than fly ash. These active pozzolans may be introduced as replacement of part of fly ash. Another possibility of their introduction is proportional reduction in both cement and ash contents. In some cases, these additives are also introduced as a replacement of part of cement. Active finegrained pozzolan can react with $\mathrm{Ca}(\mathrm{OH})_{2}$ earlier than fly ash. Thus, the inconveniences concerning with the fact that fly ash needs time to develop its activity are eliminated. Moreover, the presence of additional component may also influence (accelerate) hydration of cement (e.g. by providing of nucleation centres). Filler effect of fine particles results in more tightly microstructure.

Silica fume or nanosilica is often used for this purpose. This material is fine-grained and may cause deterioration of fluidity; however, this effect may be compensated by spherical grains of fly ash [87, 88]. Accelerating action of small amount of silica fume on early hydration of high volume fly ash mixture may be manifested in changes of shape of heat release curve while improvement in pozzolanic activity by reduction in $\mathrm{Ca}(\mathrm{OH})_{2}$ basing on TG/ DTG results. Expected effect of accelerating action of silica fume is better compressive strength of final composite.

For example, it was shown by Zhang and Islam [89] that in case of $50 \%$ cement replacement by fly ash, introduction of $1 \%$ of silica fume results in some accelerating effect. It was manifested by shorter induction period on calorimetric curve and slightly higher total heat released after $30 \mathrm{~h}$ of hydration. Compressive strength was also increased in the presence of silica fume. Increased compressive strength of high volume fly ash composite modified by the presence of silica fume was also confirmed by authors of $[54,55,90]$. Elahi et al. [91] revealed that the presence of silica fume can improve compressive strength of mixes containing $40 \%$ of low-calcium fly ash starting from 7 th day of hydration. According to authors of [91] explanation, it is an effect of better bonding between cement matrix and aggregate. Results received by Yazıcı [56] confirmed that addition of silica fume into high volume fly ash composite can effectively improve compressive strength also in case when Class $\mathrm{C}$ fly ash was used.

Better results can be achieved using nanosilica fume [85, 89]. In general, small amount of nanoparticles, such as nano- $\mathrm{Fe}_{2} \mathrm{O}_{3}$, nano- $\mathrm{CaCO}_{3}$, nano- $\mathrm{SiO}_{2}$, can improve compressive strength of cement as well as microstructure of hardened matrix on condition that nanoparticles are well dispersed [87, 92]. Exemplary literature reports concerning influence of nanoparticles on high volume fly ash mixtures are presented in Table 1.

Nanosilica, being highly amorphous powder, reacts easily with $\mathrm{Ca}(\mathrm{OH})_{2}$ and as a consequence $\mathrm{C}-\mathrm{S}-\mathrm{H}$ phase is quickly formed. This reaction occurs faster than in case of fly ash. Moreover, nanosilica makes microstructure denser and contributes greater durability. Very fine grains of nanosilica act as nucleation centres for precipitating products; thus, hydration of cement is accelerated [87, 89]. Interfacial transition zone is improved and compressive strength of final material is enhanced as a result of action of this additive despite its small amount used [87, 92, 95]. However, it should be indicated that very fine particles of nanosilica tend to agglomerate. Thus, ensuring of good homogeneity of binding mixtures by selection of appropriate method of mixing is important [85, 89].

For example, authors of [89] discussed results concerning effectiveness of silica fume and nanosilica. They showed that the presence of nanosilica accelerated hydration of cement $\left(\mathrm{C}_{3} \mathrm{~S}\right.$ especially) probably by providing additional sites for nucleation of products as well as reducing amount of calcium ions in the solution during pozzolanic reaction. As a result, $\mathrm{C}-\mathrm{S}-\mathrm{H}$ and $\mathrm{Ca}(\mathrm{OH})_{2}$ were formed faster. $\mathrm{Ca}(\mathrm{OH})_{2}$ is available for pozzolanic reaction during which additional amount of $\mathrm{C}-\mathrm{S}-\mathrm{H}$ phase may be formed. The additional peak on calorimetric curve indicates that the presence of nanosilica probably accelerated also hydration of tri-calcium aluminate and depletion of sulphate ions.

Kawashima et al. [87] revealed, basing on thermogravimetric results, that addition of nanosilica into blended cement containing $40 \%$ of fly ash causes rapid consumption of $\mathrm{Ca}(\mathrm{OH})_{2}$ during early days of hydration resulting in increasing early strength gain. This effect of strength enhancing is gradually decreased over time. Similar 
Table 1 Exemplary research reports concerning influence of nanoparticles on high volume fly ash mixtures

\begin{tabular}{|c|c|c|c|c|c|}
\hline $\begin{array}{l}\text { Amount of } \\
\text { cement } \\
\text { replacement by } \\
\text { fly ash }\end{array}$ & $\begin{array}{l}\text { Water/binder, } \\
\text { superplasticiser } \\
(\mathrm{SP})\end{array}$ & $\begin{array}{l}\text { Methods of } \\
\text { activation (used } \\
\text { nanoparticles) }\end{array}$ & $\begin{array}{l}\text { Methods of investigation of properties of } \\
\text { fresh and hardened material }\end{array}$ & $\begin{array}{l}\text { Methods of investigation of } \\
\text { hydration/activation } \\
\text { processes and formed } \\
\text { products }\end{array}$ & References \\
\hline $40,60 \%$ & 0.4 & $\begin{array}{l}\mathrm{Nano}-\mathrm{CaCO}_{3} \\
(1 \%) \text { or nano- } \\
\mathrm{SiO}_{2}(2 \%)\end{array}$ & $\begin{array}{l}\text { Compressive strength, water sorptivity, } \\
\text { rapid chloride permeability, chloride } \\
\text { diffusion, accelerated corrosion test }\end{array}$ & $\begin{array}{l}\text { TG/DTA, mercury intrusion } \\
\text { porosimetry }\end{array}$ & $\begin{array}{l}\text { Shaikh and } \\
\text { Supit [93] }\end{array}$ \\
\hline $40-70 \%$ & 0.4 & Nano- $\mathrm{SiO}_{2}(2 \%)$ & Compressive strength & XRD, SEM, BSE & $\begin{array}{l}\text { Shaikh et al. } \\
\text { [94] }\end{array}$ \\
\hline $70 \%$ & $0.3, \mathrm{SP}$ & $\begin{array}{l}\mathrm{Nano}-\mathrm{SiO}_{2} \text { and/ } \\
\text { or hydrated } \\
\text { lime, set } \\
\text { accelerator }\end{array}$ & Compressive strength & XRD, TG/DTG & $\begin{array}{l}\text { Roychandat } \\
\text { al. [85] }\end{array}$ \\
\hline $50 \%$ & $0.45, \mathrm{SP}$ & $\begin{array}{l}\mathrm{Nano}_{2}-\mathrm{SiO}_{2}(1, \\
\end{array}$ & $\begin{array}{l}\text { Initial and final setting time, compressive } \\
\text { strength, chloride ion penetrability }\end{array}$ & Calorimetry & $\begin{array}{l}\text { Zhang and } \\
\text { Islam [89] }\end{array}$ \\
\hline $40,60 \%$ & 0.4 & $\begin{array}{l}\mathrm{Nano}-\mathrm{SiO}_{2}(2, \\
4 \%)\end{array}$ & $\begin{array}{l}\text { Workability, compressive strength, water } \\
\text { absorption, rapid chloride permeability } \\
\text { test }\end{array}$ & $\begin{array}{l}\text { XRD, SEM, mercury } \\
\text { intrusion porosimetry, BSE }\end{array}$ & $\begin{array}{l}\text { Supit and } \\
\text { Shaikh } \\
\text { [95] }\end{array}$ \\
\hline $20-60 \%$ & $0.35,0.41,0.5$ & $\begin{array}{l}\text { Colloidal } \\
\text { nanosilica } \\
(2.25,5 \%)\end{array}$ & $\begin{array}{l}\text { Initial and final setting time, rheological } \\
\text { properties, fluidity, compressive } \\
\text { strength }\end{array}$ & BSE, TG/DTA, calorimetry & $\begin{array}{l}\text { Hou et al. } \\
\text { [88] }\end{array}$ \\
\hline
\end{tabular}

relationship between intensity of strength gain and time was also observed in [88].

Supit and Shaikh [95] investigated influence of small addition of nanosilica on concrete composed of 40 or $60 \%$ of fly ash (as cement replacement). They reported that in case of composite containing the highest amount of fly ash, small addition of nanosilica results in improvement in early (3-day) compressive strength while on later ages this parameter was almost the same as for concrete without nanosilica. It indicates that acceleration of cement hydration play significant role in the improvement in early mechanical properties of high volume fly ash concretes.

In case of very high volume fly ash concretes small amount of cement and resulting from this small amount of $\mathrm{Ca}(\mathrm{OH})_{2}$ may be insufficient to ensure high strength of final material and fully developed pozzolanic activity of fly ash. Moreover, it is very important to provide good homogeneity of the system. Exemplary, Roychand et al. [85] revealed that addition of hydrated lime to mixture containing cement, fly ash and nanosilica did not increase strength. Inversely, in case of greater amount of nanosilica small decrease in compressive strength was registered. The authors concluded that created additional part of $\mathrm{C}-\mathrm{S}-\mathrm{H}$ gel may act as a barrier for further reactions, e.g. it may block access of $\mathrm{Ca}(\mathrm{OH})_{2}$ to fly ash grains and in this way hinder pozzolanic reaction of fly ash [85].

Another way of activation, basing on replacement of part of material by another component of higher activity, is using highly pozzolanic aluminosilicate fine-grained materials. Wei et al. [55] registered improved compressive strength in case of concretes composed of binder containing $50 \%$ of fly ash and $50 \%$ of cement and additionally $5 \%$ of metakaolin. They stated, basing on DTA results, that in the presence of metakaolin, $\mathrm{Ca}(\mathrm{OH})_{2}$ is significantly consumed in pozzolanic reaction during 28 days of hydration. This reduction in amount of $\mathrm{Ca}(\mathrm{OH})_{2}$ in the systems was higher than in case of sample containing silica fume instead of metakaolin. Moreover, in case of metakaolin the presence of hydrated aluminosilicate phases type of $\mathrm{C}_{2} \mathrm{ASH}_{8}$ was more clearly visible.

Güneyisi and Gesoğlu [63] highlighted that retarding effect of high amount of fly ash (60\% of cement replacement), manifested by prolongation of initial and final time of set, was reduced in case of using mixture of fly ash and metakaolin. Beneficial effect of metakaolin on compressive strength was observed starting from 7 th day of hydration.

In our previous paper [20], it was proposed to use spent aluminosilicate catalyst from petrochemical industry to activate mixtures containing very high amount of fly ash. This spent catalyst is a well-known material exhibiting high pozzolanic activity and accelerating hydration of cement [96-101]. It was found that introduction of this aluminosilicate into the mixture in place of a part of fly ash results in intensification of heat release after addition of water, reduction in induction period and faster consumption of $\mathrm{Ca}(\mathrm{OH})_{2}$ in pozzolanic reaction. Addition of spent catalyst in the place of part of fly ash can accelerate to some extent hydration of fly ash-cement pastes and 
pozzolanic reaction. Small amount of available $\mathrm{Ca}(\mathrm{OH})_{2}$ is quickly depleted in the presence of the spent aluminosilicate. Thus, introducing additional amount of $\mathrm{Ca}(\mathrm{OH})_{2}$ or other alkaline component is needed [20]. Velázquez et al. [99] proposed to use mix of the spent catalyst and fly ash in case of up to $45 \%$ of replacement of cement.

Summarising this part of the paper, one can conclude that in case of very high volume fly ash binders (more than $70 \%$ of fly ash) exchange of a part of fly ash by more active pozzolana is only effective to some extent. It is possible to accelerate cement hydration and pozzolanic reaction and to improve in this way early properties of composite, but small amount of hydraulic components is not sufficient to allow fly ash to react to a greater extent, and development of high compressive strength is not possible. It is possible to improve early properties of the binders to some degree by adding additional amount of components providing substrates for pozzolanic reaction (such as $\mathrm{CaO}, \mathrm{Ca}(\mathrm{OH})_{2}$ ) or more hydraulic reactive components (e.g. rapid set cement). Chemical, alkaline especially, activation should be considered in this case for better reactivity of the mixtures as well as quicker setting, hardening and development of early compressive strength.

\section{Chemical activation of high and very high volume fly ash-cement mixtures}

Binders composed of small amounts of ordinary Portland cement or cement clinker (20-30 mass\%) and fly ash in amount of 70-80 mass\%, additionally containing separate source of alkali component, can be defined as "hybrid cements" [18, 19, 43, 74, 102, 103]. Those activated systems are mainly investigated by the team of researchers from Spain [16, 18, 19, 43, 48, 50, 104]. Exemplary literature reports concerning influence of chemical activators on hybrid cement are presented in Table 2. This type of binding mixtures may be produced not only using fly ash as the main component but also another aluminosilicate materials such as different kinds of slag [103, 105, 106], red clay brick waste [107], mixture of fly ash and slag [35, 105] or other multiple components [105], but such compositions were not discussed in this paper. Moreover, chemical activation has been used not only in the case of binders containing very high volume cement substitutions but also in case of their lower content (e.g. 40\% [108]).

\section{High alkaline activation}

In general, it is beneficial to use admixtures or solutions providing high alkaline environment for reaction. In such conditions, aluminosilicate grains of fly ash can undergo dissolution, which is the first step of formation of solid, hardened structure. In case of very high volume fly ash mixtures, alkaline activators similar to those used in geopolymers, i.e. alkali silicates and/or alkali hydroxides, may be considered. Introduction of alkali hydroxide results in higher $\mathrm{pH}$ of solution than in case of saturated solution of $\mathrm{Ca}(\mathrm{OH})_{2}$. However, there is some problem with their use, which was mentioned earlier in the introduction of this paper. Moreover, usage of highly alkaline solutions influences hydration of cement in such a way that high concentration (high $\mathrm{pH}$ of solution needed for dissolution of fly ash) inhibits hydration of clinker silicates and formation of C-S-H phase [43, 104, 108, 112-114]. Moreover, curing conditions (e.g. temperature) influence hydration processes and as a result also development of binder properties.

It should be emphasised that the presence of cement, being a source of calcium ions, in the discussed high alkali activated mixtures results in hydration processes to undergo differently as compared to that in typical alkaliactivated fly ash (geopolymers), and the formed products are also different. Various types of gels may be co-precipitated, depending on composition of the binder, type of fly ash, the kind of alkali activators and time. In case of alkali activation of hybrid cement containing high amount of fly ash, the presence of two main types of gel products, i.e. $\mathrm{C}-\mathrm{A}-\mathrm{S}-\mathrm{H}$ and $(\mathrm{N}, \mathrm{C})-\mathrm{A}-\mathrm{S}-\mathrm{H}$, can be expected. More detailed explanation of nanostructural mechanism of formation of products and their transformation with time can be found in [43, 48, 104].

Hindered hydration of clinker silicates in high $\mathrm{pH}$ may result in low compressive strength at early periods depending on type of alkaline activator, amount of cement, temperature of hardening, etc. [108, 112].

Considerably delay of normal cement hydration in the presence of solution of $\mathrm{NaOH}+\mathrm{Na}_{2} \mathrm{SiO}_{3}(\mathrm{pH}$ 13.5) was visible in calorimetric results of early cement hydration presented in [50]. In such case, thermal effect of precipitation of products was strongly reduced similarly as total heat evolved. Despite this retardation, the presence of soluble silicates beside $\mathrm{NaOH}$ is beneficial. Authors of [112] showed that in case when waterglass $+\mathrm{NaOH}$ solution was the hydrating liquid, the compressive strength was improved both after 2 and 28 days of hydration. Garcia-Lodeiro et al. [50] observed, basing on calorimetric measurements, hindering of cement hydration and some synergy effect between the ash and cement in the presence of high $\mathrm{pH}$ (additional heat effect at early period). Rivera et al. [113] investigated hybrid material hydrated with waterglass solution. They confirm that in such systems $\mathrm{Ca}(\mathrm{OH})_{2}$ is not precipitated and non-reacted alite and belite (from clinker) are present. It indicates that alkali solutions change process of hydration of Portland clinker and activate fly ash. However, not only $\mathrm{pH}$ but also the presence of soluble silica influences hardening of fly ash-rich binder 
Table 2 Exemplary research reports concerning influence of chemical activators on very high volume fly ash mixtures

\begin{tabular}{|c|c|c|c|c|c|}
\hline $\begin{array}{l}\text { Amount of } \\
\text { cement } \\
\text { replacement by } \\
\text { fly ash } / \%\end{array}$ & $\begin{array}{l}\text { Water/binder, } \\
\text { superplasticiser } \\
\text { (SP) }\end{array}$ & $\begin{array}{l}\text { Methods of activation (used } \\
\text { chemical activators) }\end{array}$ & $\begin{array}{l}\text { Methods of investigation } \\
\text { of properties of fresh and } \\
\text { hardened material }\end{array}$ & $\begin{array}{l}\text { Methods of investigation of } \\
\text { hydration/activation processes } \\
\text { and formed products }\end{array}$ & References \\
\hline $15-75$ & $0.4, \mathrm{SP}$ & Hydrated lime & Compressive strength & TG/DTG, SEM & $\begin{array}{l}\text { Lorca } \\
\text { et al. } \\
{[86]}\end{array}$ \\
\hline $60-70$ & 0.3 & $\begin{array}{l}\text { Cement kiln dust and/or } \\
\text { gypsum }\end{array}$ & $\begin{array}{l}\text { Initial and final setting } \\
\text { time, compressive } \\
\text { strength }\end{array}$ & SEM, FTIR, XRD, XRF & $\begin{array}{l}\text { Bondar } \\
\text { and } \\
\text { Coakley } \\
{[109]}\end{array}$ \\
\hline$\sim 80$ & $0.36-0.38$ & $\mathrm{CaSO}_{4} \cdot 2 \mathrm{H}_{2} \mathrm{O}$ or $\mathrm{Na}_{2} \mathrm{SO}_{4}$ & Setting time & Calorimetry, XRD, SEM-EDX & $\begin{array}{l}\text { Donatello } \\
\text { et al. } \\
\text { [16] }\end{array}$ \\
\hline$\sim 70$ & $0.46,0.5$ & $\begin{array}{l}\mathrm{CaO}, \mathrm{Na}_{2} \mathrm{SO}_{4}, \\
\mathrm{Na}_{2} \mathrm{SO}_{4}+\mathrm{CaO} \text {, grinding of } \\
\text { fly ash }\end{array}$ & Compressive strength & & $\begin{array}{l}\text { Qian et al. } \\
\text { [110] }\end{array}$ \\
\hline 70 & 0.35 & $\begin{array}{l}\text { solution of } 12.5-\mathrm{M} \\
\quad \mathrm{NaOH}+\mathrm{Na}_{2} \mathrm{SiO}_{3}\end{array}$ & Compressive strength & $\begin{array}{l}\text { XRD, BSEM/EDX, TEM/ } \\
\text { EDX, }{ }^{29} \mathrm{Si},{ }^{27} \mathrm{Al} \text { and }{ }^{23} \mathrm{Na} \\
\text { MAS NMR. }\end{array}$ & $\begin{array}{l}\text { García- } \\
\text { Lodeiro } \\
\text { et al. } \\
\text { [104] }\end{array}$ \\
\hline 70 & 0.4 & $\begin{array}{l}(\mathrm{K}, \mathrm{Na})_{2} \mathrm{SiO}_{3}(2 \%), \mathrm{Na}_{2} \mathrm{CO}_{3} \\
(3 \%) \text {, sodium oxalate }(8 \%) \\
\text { or potassium citrate }(3 \%)\end{array}$ & $\begin{array}{l}\text { Initial and final setting } \\
\text { time, chemical } \\
\text { shrinkage, compressive } \\
\text { strength }\end{array}$ & $\begin{array}{l}\text { Calorimetry, TG/DTA, XRD, } \\
\text { pore solution analyses, }\end{array}$ & $\begin{array}{l}\text { Alahrache } \\
\text { et al. } \\
\text { [36] }\end{array}$ \\
\hline 70 & 0.35 & $\begin{array}{l}\text { 12.5-M mix of } \\
\mathrm{NaOH}+\mathrm{Na}_{2} \mathrm{SiO}_{3} \\
\text { (solution) or } 2-\mathrm{M} \mathrm{Na}_{2} \mathrm{CO}_{3} \\
\text { (solution) }\end{array}$ & & $\begin{array}{l}\text { Calorimetry, XRD, FTIR, } \\
\text { BSEM/EDX }\end{array}$ & $\begin{array}{l}\text { Garcia- } \\
\text { Lodeiro } \\
\text { et al. } \\
\text { [50] }\end{array}$ \\
\hline 70 & 0.35 & $\begin{array}{l}\mathrm{NaOH}+\text { sodium silicate, } \\
\text { grinding of fly ash }\end{array}$ & Compressive strength & $\begin{array}{l}\text { XRD, SEM, TG/DTG, TPD- } \\
\text { MS, FTIR }\end{array}$ & $\begin{array}{l}\text { Mejía } \\
\text { et al. } \\
\text { [111] }\end{array}$ \\
\hline$\sim 80$ & 0.4 & $\begin{array}{l}\mathrm{Na}_{2} \mathrm{SO}_{4} \text {, grinding of fly ash } \\
\text { and cement clinker to a } \\
\text { fineness of }<45 \mu \mathrm{m}\end{array}$ & & $\begin{array}{l}\text { Calorimetry, X-ray } \\
\text { fluorescence, XRD, FTIR, } \\
\text { SEM-EDX }\end{array}$ & $\begin{array}{l}\text { Donatello } \\
\text { et al. } \\
\text { [19] }\end{array}$ \\
\hline 70 & 0.4 & $\mathrm{Na}_{2} \mathrm{SO}_{4}(3,5 \%)$ & $\begin{array}{l}\text { Initial and final setting } \\
\text { time, compressive } \\
\text { strength, expansion test }\end{array}$ & $\begin{array}{l}\text { Calorimetry, TG/DTG, } \\
\text { mercury intrusion } \\
\text { porosimetry, }{ }^{29} \mathrm{Si} \text { MAS } \\
\text { NMR, XRD, FTIR }\end{array}$ & $\begin{array}{l}\text { Dakhane } \\
\text { et al. } \\
\text { [62] }\end{array}$ \\
\hline
\end{tabular}

[112, 113]. Mejía et al. [111] proved that using $\mathrm{NaOH}$ and sodium silicate as activators of hybrid cement containing $70 \%$ of fly ash may be beneficial in case of fly ash showing high loss of ignition and exhibiting no commercial value.

Improvement in compressive strength of high alkali activated binders may be visible not only till 28th day of hydration but also in later periods. It was evidenced by authors of [104] who showed that mixture containing $70 \%$ of Class F fly ash and activated by liquid containing 12.5$\mathrm{M} \mathrm{NaOH}$ and sodium silicate exhibited 365-day compressive strength higher of about $20 \%$ compared to results for sample hydrated in water.

\section{Moderate alkali activation}

One of the advantages of hybrid cements over geopolymers is that mixtures containing cement do not require elevated temperature for hardening and forming solid structure [102, 111, 114]. Moreover, activation methods during which $\mathrm{pH}$ of solution is raised gradually in situ can be used. It may be realised by introduction of some inorganic salts into the system.

Inorganic salts, such as $\mathrm{Na}_{2} \mathrm{SO}_{4}$ or $\mathrm{Na}_{2} \mathrm{CO}_{3}$, in the presence of calcium ions can undergo reaction during which some solid products precipitate $\left(\mathrm{CaSO}_{4} \cdot 2 \mathrm{H}_{2} \mathrm{O}\right.$ or $\mathrm{CaCO}_{3}$ in case of use of $\mathrm{Na}_{2} \mathrm{SO}_{4}$ or $\mathrm{Na}_{2} \mathrm{CO}_{3}$ respectively). Sodium hydroxide $\left(\mathrm{Na}^{+}, \mathrm{OH}^{-}\right)$is also produced during the 
(a)
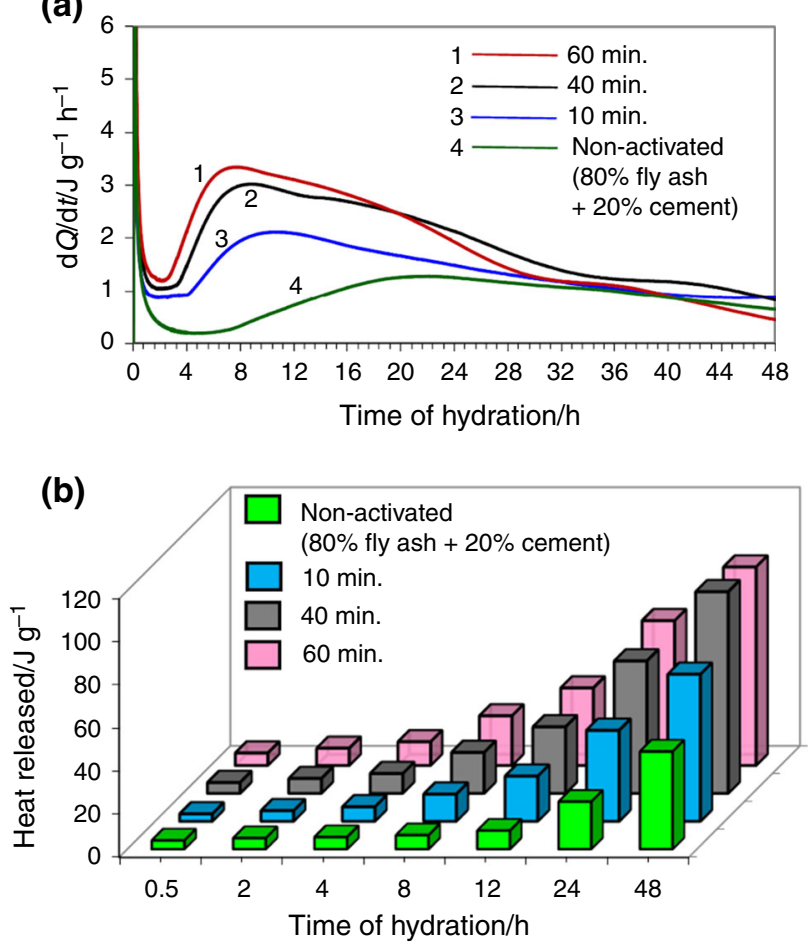

Fig. 9 Exemplary curves of heat release rate (a) and total heat released (b) for mixture activated by intergrinding dry components [fly ash, cement, $\mathrm{Ca}(\mathrm{OH})_{2}, \mathrm{Na}_{2} \mathrm{SO}_{4}$ ] for different time [planetary ball mill PM 100 (Retsch), fly ash from pulverised combustion of hard coal, water/binder $=0.5$, initial temperature of hydration $25^{\circ} \mathrm{C}$, BMR calorimeter $]\left(\mathrm{Ca}(\mathrm{OH})_{2}\right.$ and $\mathrm{Na}_{2} \mathrm{SO}_{4}$ were used in amount 10 and $4 \%$ respectively calculated in relation to total mass of cement and fly ash)

reactions and results in growing alkalinity of the solution $[16,19,36,43,49,60,74,103,110,115,116] . \mathrm{Ca}(\mathrm{OH})_{2}$ needed for the reaction may come from different sources: cement hydration, introduction of additional amount of $\mathrm{Ca}(\mathrm{OH})_{2}$ into the system or as component of used supplementary cementitious material (e.g. in case of high calcium fly ash). This method of activation, i.e. moderate alkali activation, is more secure compared to the activation performed with strong alkalis. Solutions of lower alkalinity may be used in this case, and high $\mathrm{pH}$ is generated in situ; thus, there is greater safety for workers and the environment. Moreover, the activators have relatively low impact on cement hydration and elevated temperature of hardening usually is not necessary $[36,43]$.

In general, different products of reaction may appear with the use of solutions of alkali salts. Gel of hydrated calcium silicates and aluminosilicates (similarly as in case of hydration of Portland cement) and hydrated alkali aluminosilicates (similarly as in case of alkali activated fly ash) were formed. These products do not precipitate as neat phases, but they interact and form mix which undergoes chemical and structural transformations with time.
Generally, existing of different aluminosilicate forms of variable structures depends on composition of binding mixture including $\mathrm{Ca}$ availability, $\mathrm{pH}$ and temperature. Alkali media (high $\mathrm{pH}$ ) and availability of aluminate ions change composition and structure of $\mathrm{C}-\mathrm{S}-\mathrm{H}$ phase, while calcium ions interact with $\mathrm{N}-\mathrm{A}-\mathrm{S}-\mathrm{H}$ gel forming $(\mathrm{N}, \mathrm{C})-\mathrm{A}-$ $\mathrm{S}-\mathrm{H}$ gel. In case of high lime content in the reacting solution, formation of C-A-S-H gel is favoured. Secondary products such as: ettringite, carbonates, etc., appear depending on the type of activator used as well as conditions of reaction [19, 43, 62, 105].

$\mathrm{Na}_{2} \mathrm{SO}_{4}$ is known not only as component contributing to the increase in $\mathrm{pH}$ and improving ash solubility. Its activating effects in relation to cement hydration are also known. $\mathrm{Na}_{2} \mathrm{SO}_{4}$ belongs to cement-hardening accelerators. One of hypothesis explaining this effect is faster binding of sulphate ions in form of ettringite and decreasing of concentration of calcium ions [21]. Thus, in case of mixtures of fly ash-cement activated by $\mathrm{Na}_{2} \mathrm{SO}_{4}$ both influence on hydration of cement and improvement in dissolution of fly ash grains should be considered. Additional amount of ettringite may appear. However, the presence of ettringite and its stability is strongly dependent on the composition of the liquid phase and $\mathrm{pH}$. Thus, depending on properties of fly ash (e.g. Class C or Class F fly ash), the type of cement as well as other factors (such as amount of activator, water to binder ratio, the presence of plasticising admixtures, temperature, etc.) intensity of action of $\mathrm{Na}_{2} \mathrm{SO}_{4}$ and detailed mechanism of activation may be different.

For example, we confirmed in our previous work [116] accelerating action of $\mathrm{Na}_{2} \mathrm{SO}_{4}$ in relation to the hydration of cement-fly ash paste in case of typical amount of fly ash (30 mass\%) in the binder. However, using the same amount of $\mathrm{Na}_{2} \mathrm{SO}_{4}$ in case of very high volume fly ash (80 mass\% of low-calcium fly ash) binder resulted in small degree of accelerating during early hydration process, as it was evidenced in calorimetric investigations [83].

In practice, the effect of $\mathrm{Na}_{2} \mathrm{SO}_{4}$ should result in improving strength of the binder. Acceleration of setting and satisfactory early compressive strength is very important. Wang et al. [108] reported that binder mortars composed of $40 \%$ of fly ash and $60 \%$ of cement and activated with $\mathrm{Na}_{2} \mathrm{SO}_{4}$ (standard curing at $20{ }^{\circ} \mathrm{C}$ ) exhibited almost two times higher early compressive strength compared to non-activated sample. However, in case of steam curing at $60{ }^{\circ} \mathrm{C}$ the compressive strength was similar as for the nonactivated reference. Velandia et al. [84] showed that in case of $50 \%$ cement replacement by fly ash, activation of such systems by $\mathrm{Na}_{2} \mathrm{SO}_{4}$ gives better compressive strength on early days as compared to activating by lime and quicklime. This relationship was observed mainly in case of fly ashes containing low amount of $\mathrm{Fe}_{2} \mathrm{O}_{3}$; thus, the authors of 
[84] concluded that the content of $\mathrm{Fe}_{2} \mathrm{O}_{3}$ in fly ash affected activation process.

Donatello et al. [16] showed that 2-days compressive strength of mixture containing about $80 \%$ of Class F fly ash was about two times higher than the result registered for about $80 \%$ of sand (both mixtures activated by $\mathrm{Na}_{2} \mathrm{SO}_{4}$ ). Total heat evolved during 2-days of hydration was also higher for the first mentioned composition. It confirms that strength development in the presence of $\mathrm{Na}_{2} \mathrm{SO}_{4}$ is not only result of acceleration of cement hydration but also activation of fly ash grains and their reaction.

Development of compressive strength in the presence of $\mathrm{Na}_{2} \mathrm{SO}_{4}$ activator is undoubtedly connected with transformations occurring in precipitated aluminosilicate phases. However, the presence of additional amount of sulphate ions may favour formation of ettringite which can be responsible for setting and early compressive strength and formation of which may densify the hardened structure. Results obtained by different researchers give contradictory informations about the possibility of ettringite formation in the presence of $\mathrm{Na}_{2} \mathrm{SO}_{4}$. For example formation of ettringite was observed in [84] $(50 \%$ of cement replacement by fly ash). Donatello et al. [19] noted the presence of small amount of ettringite during early stages of hydration of mixture containing higher amount, i.e. about $80 \%$, of grinded bottom ash. Because in the case of this investigation, gypsum was not present in initial mixtures (Portland cement clinker free of gypsum was used), appearing of ettringite confirms that $\mathrm{Na}_{2} \mathrm{SO}_{4}$ is responsible for their formation. Formation of some amount of ettringite during early hydration of very high volume fly ash binders activated with $\mathrm{Na}_{2} \mathrm{SO}_{4}$ was also described in [16]. Moreover, it was also affirmed in [16] that more ettringite is formed when $\mathrm{CaSO}_{4}$ was used instead of $\mathrm{Na}_{2} \mathrm{SO}_{4}$, while in case of mixture containing fine sand and activated with $\mathrm{Na}_{2} \mathrm{SO}_{4}$ ettringite did not appear.

Thus, formation of this phase is dependent on the amount of calcium ions in the systems and availability of aluminates strictly connected with $\mathrm{pH}$ of reaction environment. Alkalinity of reaction solution is a key factor. Ettringite formed in alkali activated hybrid cements has poor stability. For example, structure of ettringite may be affected by partial substitution of $\mathrm{Ca}$ by $\mathrm{Na}$ [19]. At high alkaline media and high concentration of $\mathrm{Na}^{+}$, formation of Phase $U$ and monosulphate are rather favoured. However, it also depends on content of sulphates in mixture [6, 16].

Understanding the role of calcium in these systems is very important as it influences binding phases. Research concerning influence of $\mathrm{Na}_{2} \mathrm{SO}_{4}$ on fly ash-lime paste showed that early pozzolanic reaction is accelerated and ettringite may be formed. The presence of $\mathrm{Na}_{2} \mathrm{SO}_{4}$ accelerates consumption of $\mathrm{Ca}(\mathrm{OH})_{2}$, and hydration products such as $\mathrm{C}-\mathrm{S}-\mathrm{H}$ and hydrated aluminosilicate phases are formed faster [44, 60, 117]. Li et al. [44] reported that in case of fly ash activated by $\mathrm{Ca}(\mathrm{OH})_{2}, \mathrm{CaSO}_{4}$ and $\mathrm{Na}_{2} \mathrm{SO}_{4}$ (blended together) and temperature $60{ }^{\circ} \mathrm{C}$, ettringite is formed. It confirms that sulfoaluminate phases type of ettringite may be formed not only in reaction of $\mathrm{C}_{3} \mathrm{~A}$ (constituent of cement) but also with the aluminate ions coming from breaking of glass in grains of fly ash. Shi and Day [117] confirmed that addition of $\mathrm{Na}_{2} \mathrm{SO}_{4}$ results in increase in early and later strength of pastes containing $80 \%$ of ground volcanic fly ash and $20 \%$ of $\mathrm{Ca}(\mathrm{OH})_{2}$.

Kulasuriya et al. [102] also showed that introduction of activator $\left(\mathrm{Na}_{2} \mathrm{SO}_{4}, \mathrm{Na}_{2} \mathrm{SiO}_{3}\right.$ or both of them) into fly ashlime mixture results in improving compressive strength. However, better results of compressive strength were obtained for the same chemical activation of mixture containing not only fly ash and lime but also Portland cement (about $50 \%$ of fly ash, $20 \%$ of lime and $30 \%$ of Portland cement). In this case, the best results of compressive strength were registered with the use of $\mathrm{Na}_{2} \mathrm{SO}_{4}$ as an activator. Beneficial influence of addition of $\mathrm{Na}_{2} \mathrm{SO}_{4}$ and $\mathrm{CaO}$ into fly ash-cement mixture on up to 28-day compressive strength was presented by authors of [110].

Using lime and Portland cement as constituents of the activated binder containing fly ash seems to be especially important in the case of very high volume fly ash binders. In such compositions, $\mathrm{Ca}(\mathrm{OH})_{2}$ formed during hydration of cement appears in very low amount. Moreover, it is relatively quickly depleted what can be evident on TG/DTG [20]. It causes that pozzolanic activity of fly ash cannot fully develop. In case of additionally introduced $\mathrm{Ca}(\mathrm{OH})_{2}$ component, $\mathrm{Ca}^{2+}$ ions are quickly available for reaction with activator (alkali salt) and alkali activation of fly ash can start quickly. At later periods of hydration, reaction between fly ash and $\mathrm{Ca}(\mathrm{OH})_{2}$ can contribute to the development of mechanical properties of the final composite.

Received by us calorimetric results of very high volume fly ash (about $80 \%$ ) mixture activated by $\mathrm{Na}_{2} \mathrm{SO}_{4}$ and $\mathrm{Ca}(\mathrm{OH})_{2}$ indicate that simple hand mixing of components of binder do not influence induction period significantly. For this reason, we proposed to use combined activation method: chemical $\left(\mathrm{Na}_{2} \mathrm{SO}_{4}+\mathrm{Ca}(\mathrm{OH})_{2}\right)$ and mechanical activation, during which all dry components were grinded together in planetary ball mill before adding water. In such a way, benefits from these two methods of activation can give advantageous synergy effect, what was preliminary shown by us in [49]. Further calorimetric results for hydrating pastes are very promising. It was shown that significant reduction in induction period, visible intensification of the next period of heat release related to precipitation of hydration products as well as intensification of total heat release during early $48 \mathrm{~h}$ after addition of water take place (Fig. 9). These changes are the more intense, the longer time of grinding was used. Few mechanisms of early 
activation take place in this case. Mechanical treatment of dry mixture causes better homogenisation; however, activation of grains by crushing and breaking down their surface also appears. It depends on the time and intensity of grinding. On the other hand, mechanical breach of grains causes that active components are better available to react in the presence of water. In case of fly ash + cement $+\mathrm{Ca}(\mathrm{OH})_{2}+\mathrm{Na}_{2} \mathrm{SO}_{4}$ composition, ettringite or other sulfoaluminate phases are probably formed. Early formation of ettringite-type phases seems to be very possible, when calorimetric results of mechanical activation (grinding of fly ash and cement mixture) and combined activation (grinding of fly ash, cement, $\mathrm{Ca}(\mathrm{OH})_{2}$ and $\mathrm{Na}_{2}$ $\mathrm{SO}_{4}$ mixture) were compared (Figs. 8, 9). In the first case, additional exothermic effect in form of intense peak during precipitation period appears. In the case of introduction of $\mathrm{Ca}(\mathrm{OH})_{2}$ and $\mathrm{Na}_{2} \mathrm{SO}_{4}$ into the activated mixture, this peak is not visible and induction period is effectively shortened. In the case of mechanical activation only, aluminate ions become more available and precipitate in the form of hydrated calcium aluminates, while in the presence of $\mathrm{Na}_{2} \mathrm{SO}_{4}$ these ions react fast forming ettringite or similar aluminosilicate phases. The exact mechanism of action of combined activation as well as optimisation of conditions of mechanical activation to receive the best setting time and strength results requires additional research and analysis and will be the objective of forthcoming publications.

Beneficial effect of mechanical activation (grinding of fly ash) used together with chemical activation by $\mathrm{Na}_{2} \mathrm{SO}_{4}$ was confirmed in [74, 110].

Additional amount of calcium ions in chemically activated fly ash-cement mixtures may come not only from additional introduction of lime or $\mathrm{Ca}(\mathrm{OH})_{2}$. They may also appear as component of some types of fly ashes. Dakhane et al. [62] found that in case of Class C fly ash containing mixture (the level of cement replacement was $70 \%$ ), activation with $\mathrm{Na}_{2} \mathrm{SO}_{4}$ resulted in the formation of ettringite as well as higher degree of polymerisation of silica was affirmed earlier than in case of low-calcium fly ash binder. Main product of hydration/activation was gel of (N,C)-A-S-H in case of binders containing low-calcium fly ash and $\mathrm{C}-\mathrm{A}-\mathrm{S}-\mathrm{H}$ in case of sample containing higher amount of calcium components.

Summarising, chemical activation is an effective method for enhancement reactivity of fly ash-cement system and improving setting and compressive strength. Mechanisms of action of activator are different depending on the type of chemical activator used. In general, these methods of improvement in fly ash reactivity depend on raising $\mathrm{pH}$ and improving solubility of aluminosilicate grains of fly ash. In case of some activators, secondary phases are also formed contributing to properties of final composite. Activating techniques allowing the increase in
$\mathrm{pH}$ in situ as effect of chemical reaction with activator are especially desirable. This way of raising the reactivity of the system is possible with $\mathrm{Na}_{2} \mathrm{SO}_{4}$ in the presence of calcium ions. Using combined methods of chemical and mechanical activation is especially promising.

\section{Conclusions}

In this paper, selected methods of activation of binding mixtures containing high and very high amount of fly ash have been presented. Their effectiveness, influence on kinetics of hydration and on formed solid products, modifications of setting times and compressive strength have been discussed. Possibilities of using calorimetry and thermal analysis methods for investigation of activation processes have been shown. Several conclusions have been formulated basing on the review of the literature reports as well as the results of our investigations and experience.

1. High amount of fly ash in binding mixture results in delay of hydration, lengthening time of start of setting and reduction in compressive strength especially in early ages. It is particularly visible in the case of lowcalcium fly ash. Using fly ash containing higher amount of calcium components may diminish these inconveniences because of some hydraulic properties of this type of fly ash. However, in some cases this type of fly ash may endanger durability of the final material. Thus, utilisation of calcium fly ash in high and very high amount in binding mixture is promising but needs further research.

2. Choice of activation method depends on the amount of fly ash, its kind and role in the system.

3. Mechanical activation enhances reactivity of mixture, but it may improve properties of composite only to some degree. It is very important that mechanical activation of both components of binder, it is fly ash and cement, gives better results, especially in case when intergrinding is used. Depending on conditions of grinding, physical and chemical changes in grains occur. This method of activation can give beneficial results in case of high volume fly ash mixture, however may be insufficient in case of very high content of fly ash and low content of cement.

4. Exchange of part of fly ash by more reactive pozzolanic materials results in faster developing properties of fly ash-cement mixture. It is because more active pozzolana reacts quickly forming binding phases and fly ash can contribute to the development of properties of mixture later. Moreover, very fine grains of active pozzolana may accelerate hydration of cement. However, $\mathrm{Ca}(\mathrm{OH})_{2}$ can be quickly depleted 
causing neutralisation of $\mathrm{pH}$. Fly ash cannot fully react in such case. Thus, in case of low amount of calcium components in the system, especially in case of very high amount of low-calcium fly ash, this method can be effective only to some degree.

5. Chemical activation consisting in raising $\mathrm{pH}$ causes faster dissolution of fly ash grains. High alkaline activators may inhibit hydration of cement causing reduction in early compressive strength. Solid products that are formed in such conditions are modified as compared to products of cement hydration. Different types of gel may coexist depending on type of alkali activator and conditions of reaction.

6. Recently hybrid cements composed of very high volume of fly ash and activated with some inorganic salts have met with great interest as alternative binders for Portland cement. Such materials do not require very strong alkaline solutions and elevated temperature to harden, so they are relatively safe for workers and for the natural environment.

7. Promising results may be obtained using combined method of activation, for example chemical activation with $\mathrm{Na}_{2} \mathrm{SO}_{4}$ and $\mathrm{Ca}(\mathrm{OH})_{2}$ and mechanical activation consisting in intergrinding of dry components. Further advanced investigations of such systems as well as other new compositions of hybrid cements are needed. These are the main topics of our ongoing research.

8. Calorimetry and thermal analysis are very useful for investigation of activation processes in fly ash-cement binders. Calorimetry enables to observe early hydration/activation processes. Thermal analysis gives answer about some reaction products and their estimate amount.

Open Access This article is distributed under the terms of the Creative Commons Attribution 4.0 International License (http://creative commons.org/licenses/by/4.0/), which permits unrestricted use, distribution, and reproduction in any medium, provided you give appropriate credit to the original author(s) and the source, provide a link to the Creative Commons license, and indicate if changes were made.

\section{References}

1. Gartner E, Hirao H. A review of alternative approaches to the reduction of $\mathrm{CO}_{2}$ emissions associated with the manufacture of the binder phase in concrete. Cem Concr Res. 2015;78:126-42.

2. EN 197-1. Cement-part 1: composition, specifications and conformity criteria for common cements. 2012 .

3. EN 450-1. Fly ash for concrete-part 1: definition, specifications and conformity criteria. 2012.

4. Xie Z, Xi Y. Hardening mechanisms of an alkaline-activated Class F fly ash. Cem Concr Res. 2001;31:1245-9.
5. Fernández-Jiménez A, Palomo A. Composition and microstructure of alkali activated fly ash binder: effect of the activator. Cem Concr Res. 2005;35:1984-92.

6. Fernández-Jiménez A, Palomo A, Criado M. Microstructure development of alkali-activated fly ash cement: a descriptive model. Cem Concr Res. 2005;35:1204-9.

7. Komnitsas K, Zaharaki D. Geopolymerisation: a review and prospects for the minerals industry. Miner Eng. 2007;20:1261-77.

8. Duxson P, Fernández-Jimenez A, Provis JL, Lukey GC, Palomo A, van Deventer JSJ. Geopolymer technology: the current state of the art. J Mater Sci. 2007;42:2917-33.

9. Andini S, Cioffi R, Colangelo F, Grieco T, Montagnaro F, Santoro L. Coal fly ash as raw material for the manufacture of geopolymer-based products. Waste Manag. 2008;28:416-23.

10. Pavithra P, Srinivasula Reddy M, Dinakar P, Hanumantha Rao B, Satpathy BK, Mohanty AN. A mix design procedure for geopolymer concrete with fly ash. J Cleaner Prod. 2016;133:117-25.

11. Bouzoubaâ N, Zhang MH, Bilodeau A, Malhotra VM. Laboratory-produced high-volume fly ash blended cements: physical properties and compressive strength of mortars. Cem Concr Res. 1998;28:1555-69.

12. Lam L, Wong YL, Poon CS. Degree of hydration and gel/space ratio of high-volume fly ash/cement systems. Cem Concr Res. 2000;30:747-56.

13. Arezoumandi M, Volz JS, Ortega CA, Myers JJ. Effect of total cementitious content on shear strength of high-volume fly ash concrete beams. Mater Des. 2013;46:301-9.

14. Khan MS, Prasad J, Abbas H. Effect of high temperature on high volume fly ash concrete. Arab J Sci Eng. 2013;38:1369-78.

15. Nguyen H-A, Chang T-P, Shih J-Y, Chen C-T, Nguyen T-D. Influence of circulating fluidized bed combustion (CFBC) fly ash on properties of modified high volume low calcium fly ash (HVFA) cement paste. Constr Build Mater. 2015;91:208-15.

16. Donatello S, Fernández-Jiménez A, Palomo A. Very high volume fly ash cements. Early age hydration study using $\mathrm{Na}_{2} \mathrm{SO}_{4}$ as an activator. J Am Ceram Soc. 2013;96:900-6.

17. Huang C-H, Lin S-K, Chang C-S, Chen H-J. Mix proportions and mechanical properties of concrete containing very highvolume of Class F fly ash. Constr Build Mater. 2013;46:71-8.

18. Donatello S, Palomo A, Fernández-Jiménez A. Durability of very high volume fly ash cement pastes and mortars in aggressive solutions. Cem Concr Compos. 2013;38:12-20.

19. Donatello S, Maltseva O, Fernández-Jimenez A, Palomo A. The early age hydration reactions of a hybrid cement containing a very high content of coal bottom ash. J Am Ceram Soc. 2014;97:929-37.

20. Wilińska I, Pacewska B. Calorimetric and thermal analysis studies on the influence of waste aluminosilicate catalyst on the hydration of fly ash-cement paste. J Therm Anal Calorim. 2014;116:689-97.

21. Kurdowski W. Chemia cementu i betonu. Kraków: Stowarzyszenie Producentów Cementu; 2010 (in Polish).

22. Taylor HFW. Cement chemistry. 2nd ed. London: Thomas Telford; 1997.

23. Hannesson G, Kuder K, Shogren R, Lehman D. The influence of high volume of fly ash and slag on the compressive strength of self-consolidating concrete. Constr Build Mater. 2012;30:161-8.

24. Jackiewicz-Rek W. Betony wysokopopiołowe. Mater Bud. 2010;10:18-20 (in Polish).

25. Bentz DP, Sato T, de la Varga I, Weiss WJ. Fine limestone additions to regulate setting in high volume fly ash mixtures. Cem Concr Compos. 2012;34:11-7.

26. Khokhar MIA, Roziere E, Turcry P, Grondin F, Loukili A. Mix design of concrete with high content of mineral additions: 
optimisation to improve early age strength. Cem Concr Compos. 2010;32:377-85.

27. Duran Atiş C. Strength properties of high-volume fly ash roller compacted and workable concrete, and influence of curing condition. Cem Concr Res. 2005;35:1112-21.

28. Kledyński Z, Machowska A, Pacewska B, Wilińska I. Investigation of hydration products of fly ash-slag pastes. J Therm Anal Calorim. 2017;130:351-63.

29. Dung NT, Chang T-P, Chen C-T, Yang T-R. Cementitious properties and microstructure of an innovative slag eco-binder. Mater Struct. 2016;49:2009-24.

30. Aydin E, Şahan Arel H. Characterization of high-volume fly-ash cement pastes for sustainable construction applications. Constr Build Mater. 2017;157:97-107.

31. Wang Q, Yan P, Feng J. Design of high-volume fly ash concrete for a massive foundation slab. Mag Concr Res. 2013;65:71-81.

32. Li X, Hua Zhou S, Qin Wang Z, Tao Xiao K. Project application of high volume fly ash concrete. Appl Mech Mater. 2011;71-78:684-7.

33. Kumar Mehta P. High-performance, high-volume fly ash concrete for sustainable development. In: Kejin Wang, editor. Proceedings of the international workshop on sustainable development and concrete technology. Beijing, China: Iowa State University, USA; 2004. pp. 3-14.

34. Bilodeau A, Mohan Malhotra V. High-volume fly ash system: concrete solution for sustainable development. ACI Mater J. 2000;97:41-8.

35. Qu B, Martin A, Pastor JY, Palomo A, Fernández-Jiménez A. Characterisation of pre-industrial hybrid cement and effect of precuring temperature. Cem Concr Compos. 2016;73:281-8.

36. Alahrache S, Winnefeld F, Champenois J-B, Hesselbarth F, Lothenbach B. Chemical activation of hybrid binders based on siliceous fly ash and Portland cement. Cem Concr Compos. 2016;66:10-23.

37. Nocun-Wczelik W, Trybalska B, Zugaj E. Application of calorimetry as a main tool in evaluation of the effect of carbonate additives on cement hydration. J Therm Anal Calorim. 2013;113:351-6.

38. Han F, Zhang Z, Liu J, Yan P. Hydration kinetics of composite binder containing fly ash at different temperatures. J Therm Anal Calorim. 2016;124:1691-703.

39. Fanghui H, Qiang W, Mutian L, Yingjun M. Early hydration properties of composite binder containing limestone powder with different finenesses. J Therm Anal Calorim. 2016;123:1141-51.

40. Pane I, Hansen W. Investigation of blended cement hydration by isothermal calorimetry and thermal analysis. Cem Concr Res. 2005;35:1155-64.

41. Monteagudo SM, Moragues A, Gálvez JC, Casati MJ, Reyes E. The degree of hydration assessment of blended cement pastes by differential thermal and thermogravimetric analysis. Morphological evolution of the solid phases. Thermochim Acta. 2014;592:37-51.

42. Kaminskas R, Cesnauskas V, Kubiliute R. Influence of different artificial additives on Portland cement hydration and hardening. Constr Build Mater. 2015;95:537-44.

43. Garcia-Lodeiro I, Donatello S, Fernandez-Jimenez A, Palomo A. Hydration of hybrid alkaline cement containing a very large proportion of fly ash: a descriptive model. Materials. 2016;9:605.

44. Li D, Chen Y, Shen J, Su S, Wu X. The influence of alkalinity on activation and microstructure of fly ash. Cem Concr Res. 2000;30:881-6.

45. Pacewska B, Blonkowski G, Wilińska I. Studies on the pozzolanic and hydraulic properties of fly ashes in model systems. J Therm Anal Calorim. 2008;94:469-76.
46. Giergiczny Z. The hydraulic activity of high calcium fly ash. J Therm Anal Calorim. 2006;83:227-32.

47. Sheng G, Li Q, Zhai J, Li F. Self-cementitious properties of fly ashes from CFBC boilers co-firing coal and high-sulphur petroleum coke. Cem Concr Res. 2007;37:871-6.

48. García-Lodeiro G, Maltseva O, Palomo A, Fernández-Jiménez A. Hybrid alkaline cements: part I. Fundamentals. Rom J Mater. 2012;42:330-5.

49. Wilińska I, Pacewska B. Zastosowanie kalorymetrii we wstępnych badaniach aktywowanych mieszanek popiołowo-cementowych. Przem Chem. 2017;96:761-5 (in Polish).

50. Garcia-Lodeiro I, Fernandez-Jimenez A, Palomo A. Hydration kinetics in hybrid binders: early reaction stages. Cem Concr Compos. 2013;39:82-92.

51. Mostafa NY, Brown PW. Heat of hydration of high reactive pozzolans in blended cements: isothermal conduction calorimetry. Thermochim Acta. 2005;435:162-7.

52. Hu J, Ge Z, Wang K. Influence of cement fineness and water-tocement ratio on mortar early-age heat of hydration and set times. Constr Build Mater. 2014;50:657-63.

53. Deschner F, Winnefeld F, Lothenbach B, Seufert S, Schwesig P. Hydration of Portland cement with high replacement by siliceous fly ash. Cem Concr Res. 2012;42:1389-400.

54. Barbhuiya SA, Gbagbo JK, Russell MI, Basheer PAM. Properties of fly ash concrete modified with hydrated lime and silica fume. Constr Build Mater. 2009;23:3233-9.

55. Wei X, Zhu H, Li G, Zhang C, Xiao L. Properties of high volume fly ash concrete compensated by metakaolin or silica fume. J Wuhan Univ Technol Mater Sci Ed. 2007;22:728-32.

56. Yazıc1 $\mathrm{H}$. The effect of silica fume and high-volume Class $\mathrm{C}$ fly as on mechanical properties, chloride penetration and freezethaw resistance of self-compacting concrete. Constr Build Mater. 2008;22:456-62.

57. Myadraboina H, Setunge S, Patnaikuni I. Pozzolanic Index and lime requirement of low calcium fly ashes in high volume fly ash mortar. Constr Build Mater. 2017;131:690-5.

58. Bae S, Meral C, Oh J, Moon J, Kunz M, Monteiro PJM. Characterization of morphology and hydration products of highvolume fly ash paste by monochromatic scanning X-ray microdiffraction ( $\mu$-SXRD). Cem Concr Res. 2014;59:155-64.

59. Giergiczny Z. Popioły lotne z dużą zawartością wapnia (high calcium fly ash). Cem Wapno Beton. 2005;10(72):271-82.

60. Pacewska B, Wilińska I. Comparative investigations of influence of chemical admixtures on pozzolanic and hydraulic activities of fly ash with the use of thermal analysis and infrared spectroscopy. J Therm Anal Calorim. 2015;120:119-27.

61. Ben Haha M, Lothenbach B, Le Saout G, Winnefeld F. Influence of slag chemistry on the hydration of alkali-activated blast-furnace slag-part II: effect of $\mathrm{Al}_{2} \mathrm{O}_{3}$. Cem Concr Res. 2012;42:74-83.

62. Dakhane A, Tweedley S, Kailas S, Marzke R, Neithalath N. Mechanical and microstructural characterization of alkali sulfate activated high volume fly ash binders. Mater Des. 2017;122:236-46.

63. Güneyisi E, Gesoğlu M. Properties of self-compacting mortars with binary and ternary cementitious blends of fly ash and metakaolin. Mater Struct. 2008;41:1519-31.

64. Kubissa W, Wilińska I, Pałuba M. Badanie właściwości betonów cementowych wykonanych z udziałem odpadów przemysłowych. Prz Bud. 2013;84:35-9 (in Polish).

65. Aydin S, Karatay C, Baradan B. The effect of grinding process on mechanical properties and alkali-silica reaction resistance of fly ash incorporated cement mortars. Powder Technol. 2010;197:68-72. 
66. Ilić B, Radonjanin V, Malešev M, Zdujić M, Mitrović A. Effects of mechanical and thermal activation on pozzolanic activity of kaolin containing mica. Appl Clay Sci. 2016;123:173-81.

67. Pacewska B, Wilińska I, Bukowska M, Blonkowski G, NocuńWczelik W. An attempt to improve the pozzolanic activity of waste aluminosilicate catalyst. J Therm Anal Calorim. 2004;77:133-42.

68. Cordeiro GC, Tavares LM, Toledo Filho RD. Improved pozzolanic activity of sugar cane bagasse ash by selective grinding and classification. Cem Concr Res. 2016;89:269-75.

69. Kumar R, Kumar S, Mehrotra SP. Towards sustainable solutions for fly ash through mechanical activation. Resour Conserv Recycl. 2007;52:157-79.

70. Patil AG, Anandhan S. Influence of planetary ball milling parameters on the mechano-chemical activation of fly ash. Powder Technol. 2015;281:151-8.

71. Cristelo N, Tavares P, Lucas E, Miranda T, Oliveira D. Quantitative and qualitative assessment of the amorphous phase of a Class $\mathrm{F}$ fly ash dissolved during alkali activation reactionseffect of mechanical activation, solution concentration and temperature. Compos B. 2016;103:1-14.

72. Hela R, Orsáková D. The mechanical activation of fly ash. Procedia Eng. 2013;65:87-93.

73. Bondar D, Coakley E. Effect of grinding on early age performance of high volume fly ash ternary blended pastes with CKD \& OPC. Constr Build Mater. 2017;136:153-63.

74. du Toit G, van der Merwe EM, Kearsley EP, McDonald M, Kruger RA. Compressive strength of chemically and mechanically activated aluminosilicate systems. In: 2015 world of coal ash conference in Nasvhille. 2015. http://www.flyash.info/2015/ 073-dutoit-2015.pdf. Accessed 15 Aug 2017.

75. Zhao J, Wang D, Wang X, Liao S, Lin H. Ultrafine grinding of fly ash with grinding aids: impact on particle characteristics of ultrafine fly ash and properties of blended cement containing ultrafine fly ash. Constr Build Mater. 2015;78:250-9.

76. Supit SWM, Shaikh FUA, Sarker PK. Effect of ultrafine fly ash on mechanical properties of high volume fly ash mortar. Constr Build Mater. 2014;51:278-86.

77. Li Hui, Chen Ying, Cao Yan, Liu Guijian, Li Buqing. Comparative study on the characteristics of ball-milled coal fly ash. J Therm Anal Calorim. 2016;124:839-46.

78. Payá J, Monzó J, Borrachero MV, Peris-Mora E, Amahjour F. Mechanical treatment of fly ashes. Part IV. Strength development of ground fly ash-cement mortars cured at different temperatures. Cem Concr Res. 2000;30:543-51.

79. Jaturapitakkul C, Kiattikomol K, Sata V, Leekeeratikul T. Use of ground coarse fly ash as a replacement of condensed silica fume in producing high-strength concrete. Cem Concr Res. 2004:34:549-55.

80. Roychand R, De Silva S, Law D, Setunge S. Micro and nano engineered high volume ultrafine fly ash cement composite with and without additives. Int $\mathbf{J}$ Concr Struct Mater. 2016;10:113-24.

81. Bentz DP, Ferraris CF. Rheology and setting of high volume fly ash mixtures. Cem Concr Compos. 2010;32:265-70.

82. McCarthy MJ, Dhir RK. Development of high volume fly ash cements for use in concrete construction. Fuel. 2005;84:1423-32.

83. Pacewska B, Wilińska I. Hydration of cement composites containing large amount of waste materials. Procedia Eng. 2013;57:53-62.

84. Velandia DF, Lynsdale CJ, Provis JL, Ramirez F, Gomez AC. Evaluation of activated high volume fly ash systems using $\mathrm{Na}_{2} \mathrm{SO}_{4}$, lime and quicklime in mortars with high loss on ignition fly ashes. Constr Build Mater. 2016;128:248-55.
85. Roychand R, De Silva S, Law D, Setunge S. High volume fly ash cement composite modified with nano silica, hydrated lime and set accelerator. Mater Struct. 2016;49:1997-2008.

86. Lorca P, Calabuig R, Benlloch J, Soriano L, Payá J. Microconcrete with partial replacement of Portland cement by fly ash and hydrated lime addition. Mater Des. 2014;64:535-41.

87. Kawashima S, Hou P, Corr DJ, Shah SP. Modification of cement-based materials with nanoparticles. Cem Concr Compos. 2013;36:8-15.

88. Hou P, Kawashima S, Wang K, Corr DJ, Qian J, Shah SP. Effects of colloidal nanosilica on rheological and mechanical properties of fly ash-cement mortar. Cem Concr Compos. 2013;35:12-22.

89. Zhang M-H, Islam J. Use of nano-silica to reduce setting time and increase early strength of concretes with high volumes of fly ash or slag. Constr Build Mater. 2012;29:573-80.

90. Rashad AM. An exploratory study on high-volume fly ash concrete incorporating silica fume subjected to thermal loads. J Clean Prod. 2015;87:735-44.

91. Elahi A, Basheer PAM, Nanukuttan SV, Khan QUZ. Mechanical and durability properties of high performance concretes containing supplementary cementitious materials. Constr Build Mater. 2010;24:292-9.

92. Li H, Xiao H-g, Yuan J, Ou J. Microstructure of cement mortar with nano-particles. Compos Part B. 2004;35:185-9.

93. Shaikh FUA, Supit SWM. Chloride induced corrosion durability of high volume fly ash concretes containing nano particles. Constr Build Mater. 2015;99:208-25.

94. Shaikh FUA, Supit SWM, Sarker PK. A study on the effect of nano silica on compressive strength of high volume fly ash mortars and concretes. Mater Des. 2014;60:433-42.

95. Supit SWM, Shaikh FUA. Durability properties of high volume fly ash concrete containing nano-silica. Mater Struct. 2015;48:2431-45.

96. Pacewska B, Bukowska M, Wilińska I, Swat M. Modification of the properties of concrete by a new pozzolan. A waste catalyst from the catalytic process in a fluidized bed. Cem Concr Res. 2002;32:145-52.

97. Pacewska B, Wilińska I, Bukowska M, Nocuń-Wczelik W. Effect of waste aluminosilicate material on cement hydration and properties of cement mortars. Cem Concr Res. 2002;32:1823-30.

98. Pacewska B, Wilińska I, Bukowska M. Calorimetric investigations of the influence of waste aluminosilicate on the hydration of different cements. J Therm Anal Calorim. 2009;97:61-6.

99. Velázquez S, Monzó J, Borrachero MV, Soriano L, Payá J. Evaluation of the pozzolanic activity of spent FCC catalyst/fly ash mixtures in Portland cement pastes. Thermochim Acta. 2016;632:29-36.

100. Pinto CA, Büchler PM, Dweck J. Pozzolanic properties of a residual FCC catalyst during the early stages of cement hydration. Evaluation by thermal analysis. J Therm Anal Calorim. 2007;87:715-20.

101. Hsu K-C, Tseng Y-S, Ku F-F, Su N. Oil cracking waste catalyst as an active pozzolanic material for superplasticized mortars. Cem Concr Res. 2001;31:1815-20.

102. Kulasuriya C, Vimonsatit V, Dias WPS, De Silva P. Design and development of alkali pozzolan cement (APC). Constr Build Mater. 2014;68:426-33.

103. Martauz P, Janotka I, Strigáč J, Bačuvčik M. Fundamental properties of industrial hybrid cement: utilization in readymixed concretes and shrinkage-reducing applications. Mater Constr. 2016;66:1-14.

104. García-Lodeiro I, Fernández-Jiménez A, Palomo A. Variation in hybrid cements over time. Alkaline activation of fly ash-portland cement blends. Cem Concr Res. 2013;52:112-22. 
105. Shi C, Fernández Jiménez A, Palomo A. New cements for the 21st century: the pursuit of an alternative to Portland cement. Cem Concr Res. 2011;41:750-63.

106. Angulo-Ramírez DE, de Gutiérrez RM, Puertas F. Alkali-activated Portland blast-furnace slag cement: mechanical properties and hydration. Constr Build Mater. 2017;140:119-28.

107. Robayo RA, Mulford A, Munera J, Mejía de Gutiérrez R. Alternative cements based on alkali-activated red clay brick waste. Constr Build Mater. 2016;128:163-9.

108. Wang D, Wang Q, Fang Z. Influence of alkali activators on the early hydration of cement-based binders under steam curing condition. J Therm Anal Calorim. 2017. https://doi.org/10.1007/ s10973-017-6528-5.

109. Bondar D, Coakley E. Use of gypsum and CKD to enhance early age strength of high volume fly ash (HVFA) pastes. Constr Build Mater. 2014;71:93-108.

110. Qian J, Shi C, Wang Z. Activation of blended cements containing fly ash. Cem Concr Res. 2001;31:1121-7.

111. Mejía JM, Rodríguez E, Mejía de Gutiérrez R, Gallego N. Preparation and characterization of a hybrid alkaline binder based on a fly ash with no commercial value. J Clean Prod. 2015;104:346-52.
112. Palomo A, Fernández-Jiménez A, Kovalchuk G, Ordoñez LM, Naranjo MC. OPC-fly ash cementitious systems: study of gel binders produced during alkaline hydration. J Mater Sci. 2007;42:2958-66.

113. Rivera JF, Mejía JM, Mejía de Gutierrez R, Gordillo M. Hybrid cement based on the alkali activation of by-products of coal. Rev Constr. 2014;13:31-9.

114. Moon J, Wang Z, Kim MO, Chun S-C. Strength enhancement of alkaline activated fly ash cured at ambient temperature by delayed activation of substituted OPC. Constr Build Mater. 2016;122:659-66.

115. Hemalatha T, Ramaswamy A. A review on fly ash characteristics-towards promoting high volume utilization in developing sustainable concrete. J Clean Prod. 2017;147:546-59.

116. Pacewska B, Wilińska I, Blonkowski G. Investigations of cement early hydration in the presence of chemically activated fly ash. Use of calorimetry and infrared absorption methods. J Therm Anal Calorim. 2008;93:769-76.

117. Shi C, Day RL. Pozzolanic reaction in the presence of chemical activators. Part I. Reaction kinetics. Cem Concr Res. 2000;30:51-8. 